\title{
Design, Analysis and Performance Evaluation of Electrical Power Subsystem Based on Triple-Junctions Solar PV Cells and SEPIC for a Conceptual 1u Cubesat Mission
}

\author{
Ali Danladi, Mehmet Kurtoğlu, Ahmet Mete Vural \\ Department of Electrical and Electronics Engineering \\ Gaziantep University, Gaziantep, Turkey \\ E-mail: abalhafsa@gmail.com,mkurtoglu@gantep.edu.tr, \\ mete.vural@gaziantep.edu.tr
}

\begin{abstract}
This study aims to popularize low voltage power supply design especially for space satellite Cubesat mission and other portable consumer electronic devices. In this context, a preliminary design of an electrical power subsystem (EPS) is carried out for a conceptual $1 \mathrm{u}$ Cubesat mission in this paper. Mathematical modeling of the basic elements of the EPS is presented. Photovoltaic (PV) power generation system that is selected is made up of triple-junction solar cells, and the battery charging system based on lithium technology as well as the power conditioning converters are selected based on single ended primary inductance converter topology popularly abbreviated as SEPIC. Triple-junction solar PV cell results are verified by comparing with the datasheet values. A maximum power point tracking algorithm which is known as perturb and observe is implemented and proportional-integral controller is used for the SEPIC. All of these are well analyzed, mathematically modeled and simulated. Feasibility of the designed EPS is verified by comparing with similar devices from different manufacturers.
\end{abstract}

Key Words: Space technology, CubeSat, Electrical power subsystem, DC/DC power converters, Solar photovoltaic cells.

\section{INTRODUCTION}

The space industry stakeholders need a very ideal electrical power subsystem (EPS) that can work perfectly well under constraints, if achievable, function beyond the mission duration. So far, only solar photovoltaic (PV) system can be employed for the power generation on a CubeSat looking at specifications and design guidelines given in [1]. This is especially required if the satellite is to operate in a region of space called the low earth orbit (LEO) since there are frequent eclipses on its path [2]. In 
addition to solar PV system, load regulators (power conditioning and distribution) must be also included in the satellite system [1], [3], and [5]. In [2], the main objective of CubeSat program is given to provide opportunities especially for university students to test their designs and launch overheads particularly for experiments, other commercial and scientific demonstrations purposes. Advancement of a budget-constrained EPS would require that the design engineers develop custom or use commercial-off-the-shelf components like the solar PV cells, lithium based batteries and the other electronic components for the power supply. Appropriate design practice therefore is expected to be the order to ensure that the design complies with the requirements in [1]. According to the works presented in [1]-[5], the EPS contains the solar PV cells for generating power required, a series converter for maximum power point tracking (MPPT), a voltage regulator for power conditioning and a lithium battery storage unit.

The employment of PV cell in space satellites have directed the researchers to focus on the modeling, simulation and performance evaluation of relatively new technologies. Therefore, they need to verify the demands being reported by the manufacturers and design MPPT algorithms [6]-[8]. Hence, there is a requirement to design hardware that can extract the maximum power from PV cells at all times, that's why, it's necessary to carry out modeling of the PV cell with multi-junction solar cells [9]. Viability of CubeSat technology necessitates this approach since it has become popular over the years among scientists and other professional engineers.

The main purpose of this study is to design and simulate all the main building blocks of an EPS for a conceptual $1 \mathrm{U}$ CubeSat that can safely, effectively and continuously supply all its loads in LEO without any failure for the intended mission lifetime where it would be employed. Objective of concept is also to have a simple and cost effective EPS design that can be reused on any type of mission of its kind. When the study is briefly overviewed, the produced energy from PV cell must be controlled using DC/DC converter in order to provide a regulated voltage for Cubesat mission. Among the existing DC/DC converters in the literature, single ended primary inductance converter (SEPIC) topology that is controlled with PI controller is preferred for this application. Also, lithium technology is used for battery storage system. The overall designed EPS system is illustrated in Figure 1. In order to achieve the stated objectives above, the following tasks are conducted. A literature review presented in Table 1 on CubeSat projects and EPS designs of these projects are exhibited. Design of a skeletal and simple reusable CubeSat EPS that can be used in LEO missions or other uses in portable consumer electronics like mobile phones is achieved. A review on the available and most viable PV cells is also carried out and from among the bests, a choice is made based on heritage and reported performance of the cells. Most popular load voltage regulators and switched-mode power supplies for power conditioning and distribution are reviewed and a decision is taken on which one to employ in this application. A review with a view to 
considering the battery technologies and associated efficiencies available for space applications especially LEO is also attempted and the most suitable selected. Solar PV cells are mathematically modeled and simulated in simulation environment. 3.3 V and 5.0 V DC power supply and MPPT based battery charging converters are designed, modeled and simulated by using state-space averaging technique. A comparison is carried out with similar studies and effectiveness of designed concept is presented. The main contributions of this paper are briefly presented as in the followings. EPS based on triple-junctions solar PV cells and SEPIC is designed and mathematically analyzed, and verification of EPS is done in a comparative ways. The obtained results can be beneficial for power supply designers. In addition, space industry stakeholders can take the advantageous of the simulation results for space satellite Cubesat mission without necessarily having to carry out extensive literature review thanks to this study.

The organization of this paper is as follows. In Section II, the theory and mathematical modeling of triple-junction solar cell is introduced together with modeling and control of SEPIC. Section III presents the simulation results. Simulation validation is shown by comparing with datasheet of triple-junction PV cell at STC and, I-V and P-V characteristics of cell under various conditions are exhibited. Voltage and current output characteristics are given with satisfactory outcomes for 3.3V and 5V SEPIC, respectively. Evaluation of obtained results is discussed by verifying the superior performance of designed EPS in Section IV. Finally, Section V concludes this paper.

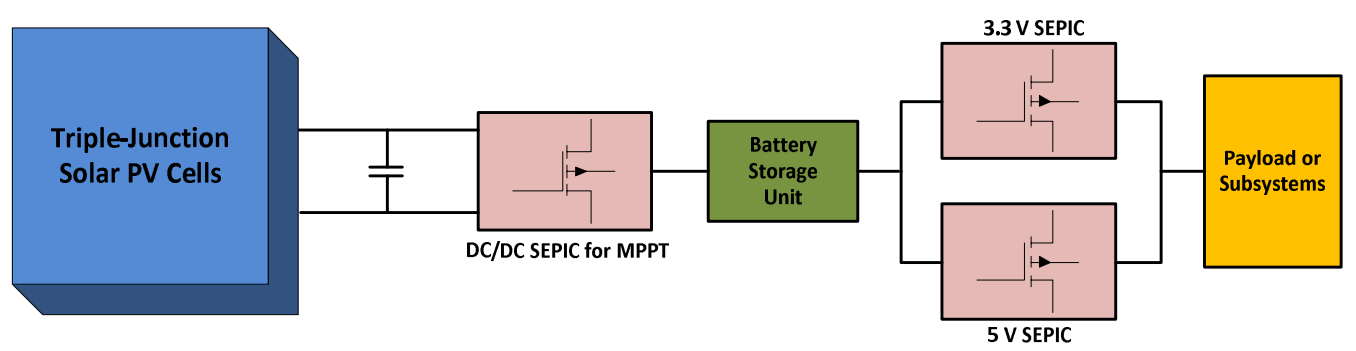

Figure 1. Schematic diagram of designed EPS system 
Table 1: A review of some University CubeSat projects

\begin{tabular}{|c|c|c|c|c|c|c|}
\hline Name & Owner & Type & $\begin{array}{c}\text { Solar Cell } \\
\text { Technology }\end{array}$ & $\begin{array}{l}\text { Battery Cell } \\
\text { Technology }\end{array}$ & Architecture & $\begin{array}{c}\text { Bus } \\
\text { Voltages }\end{array}$ \\
\hline NCube1 & $\begin{array}{l}\text { Norwegian } \\
\text { University }\end{array}$ & $1 \mathrm{U}$ & Not Sure & Not Sure & Not Sure & $\begin{array}{c}3.3 \mathrm{~V} \& \\
5.0 \mathrm{~V}\end{array}$ \\
\hline DICE & $\begin{array}{l}\text { Utah State } \\
\text { University }\end{array}$ & $1.5 \mathrm{U}$ & $\begin{array}{c}\text { Triple } \\
\text { Junction }\end{array}$ & $\begin{array}{l}\text { Lithium - } \\
\text { Polymer }\end{array}$ & $\begin{array}{l}\text { Centralized } \\
\text { \& PPT }\end{array}$ & $\begin{array}{c}8.2 \mathrm{~V} \\
\text { (Unregula } \\
\text { ted), 5.0V } \\
\text { and 3.3V } \\
\end{array}$ \\
\hline Name & Owners & Type & $\begin{array}{c}\text { Solar Cell } \\
\text { Technology }\end{array}$ & $\begin{array}{l}\text { Battery Cell } \\
\text { Technology }\end{array}$ & Architecture & $\begin{array}{c}\text { Bus } \\
\text { Voltages }\end{array}$ \\
\hline $\begin{array}{l}\text { NUTS- } \\
\text { NTNU }\end{array}$ & $\begin{array}{l}\text { Norwegian } \\
\text { University }\end{array}$ & $2 \mathrm{U}$ & $\mathrm{N} / \mathrm{A}$ & $\begin{array}{l}\text { Lithium- } \\
\text { ferrite }\end{array}$ & $\begin{array}{l}\text { MPPT and } \\
\text { Distributed }\end{array}$ & $\begin{array}{c}3.3 \mathrm{~V} \& \\
5.0 \mathrm{~V}\end{array}$ \\
\hline $\begin{array}{c}\text { Aalto - } \\
1\end{array}$ & $\begin{array}{c}\text { Aalto } \\
\text { University }\end{array}$ & $3 U$ & $\begin{array}{c}\text { Triple } \\
\text { Junction }\end{array}$ & $\begin{array}{l}\text { Lithium } \\
\text { Polymer } \\
\text { cells }\end{array}$ & $\begin{array}{l}\text { MPPT and } \\
\text { Centralized }\end{array}$ & $\begin{array}{c}3.3 \mathrm{~V}, 5.0 \mathrm{~V} \\
\text { and } 12 \mathrm{~V}\end{array}$ \\
\hline $\begin{array}{c}\text { Aalto - } \\
2\end{array}$ & $\begin{array}{c}\text { Aalto } \\
\text { University }\end{array}$ & $2 \mathrm{U}$ & $\begin{array}{c}\text { Triple } \\
\text { Junction }\end{array}$ & Lithium-ion & $\begin{array}{c}\text { MPPT and } \\
\text { Centralized }\end{array}$ & $\begin{array}{l}3.3 \mathrm{~V} \text { and } \\
5.0 \mathrm{~V}\end{array}$ \\
\hline NMTSat & $\begin{array}{l}\text { New } \\
\text { Mexico } \\
\text { Tech. }\end{array}$ & $3 U$ & $\begin{array}{c}\text { Triple } \\
\text { Junction }\end{array}$ & $\mathrm{N} / \mathrm{A}$ & MPPT & $\begin{array}{l}3.3 \mathrm{~V} \text { and } \\
5.0 \mathrm{~V}\end{array}$ \\
\hline $\begin{array}{l}\text { Concept } \\
\text { ual } \\
\text { Design }\end{array}$ & $\begin{array}{c}\text { Islamic } \\
\text { Azad } \\
\text { University }\end{array}$ & $\begin{array}{l}\text { Nano } \\
\text { satell } \\
\text { ite }\end{array}$ & $\begin{array}{c}\text { Multi } \\
\text { Junction }\end{array}$ & $\begin{array}{l}\text { Lithium-ion } \\
\text { battery }\end{array}$ & $\begin{array}{l}\text { MPPT and } \\
\text { Distributed }\end{array}$ & $10.5 \mathrm{~V}$ \\
\hline $\begin{array}{l}\text { TINYSC } \\
\text { OPE }\end{array}$ & $\begin{array}{c}\text { Naval } \\
\text { Postgradua } \\
\text { te } \\
\text { School } \\
\end{array}$ & $\begin{array}{c}5 \mathrm{U} \text { or } \\
6 \mathrm{U}\end{array}$ & $\begin{array}{l}\text { Advanced } \\
\text { Triple } \\
\text { Junction }\end{array}$ & Lithium-ion & Not sure & $\begin{array}{c}3.3 \mathrm{~V}, 5.0 \mathrm{~V} \\
\text { and } 12 \mathrm{~V}\end{array}$ \\
\hline $\begin{array}{c}\text { CubeST } \\
\text { AR }\end{array}$ & $\begin{array}{c}\text { University } \\
\text { of Oslo }\end{array}$ & $2 \mathrm{U}$ & $\begin{array}{c}\text { Multi } \\
\text { Junction }\end{array}$ & $\begin{array}{c}\text { LiFeP04 } \\
\text { battery cell }\end{array}$ & $\begin{array}{c}\text { MPPT and } \\
\text { Distributed }\end{array}$ & $\begin{array}{l}3.3 \mathrm{~V} \text { and } \\
5.0 \mathrm{~V}\end{array}$ \\
\hline $\begin{array}{c}\text { ESTCub } \\
\mathrm{e}-1\end{array}$ & $\begin{array}{l}\text { University } \\
\text { of Estonia }\end{array}$ & $1 \mathrm{U}$ & $\mathrm{N} / \mathrm{A}$ & Lithium-ion & $\begin{array}{c}\text { MPPT and } \\
\text { Distributed }\end{array}$ & $\mathrm{N} / \mathrm{A}$ \\
\hline ECOSat & $\begin{array}{l}\text { University } \\
\text { of Victoria }\end{array}$ & $\begin{array}{l}\text { Not } \\
\text { clear }\end{array}$ & $\begin{array}{l}\text { Ultra-Triple } \\
\text { Junction }\end{array}$ & Lithium-ion & $\begin{array}{c}\text { DET Direct } \\
\text { Energy } \\
\text { Transfer }\end{array}$ & $\begin{array}{c}3.3 \mathrm{~V}, 5.0 \mathrm{~V} \\
\text { and } 7.0 \mathrm{~V}\end{array}$ \\
\hline $\begin{array}{c}\text { CubeCa } \\
\text { t-1 }\end{array}$ & $\begin{array}{c}\text { Universitat } \\
\text { Politecnica } \\
\text { du } \\
\text { Catalunya } \\
\end{array}$ & $1 \mathrm{U}$ & $\mathrm{N} / \mathrm{A}$ & $\mathrm{N} / \mathrm{A}$ & $\begin{array}{l}\text { MPPT and } \\
\text { Distributed } \\
\text { battery bus }\end{array}$ & $\begin{array}{l}3.3 \mathrm{~V} \text { and } \\
5.0 \mathrm{~V}\end{array}$ \\
\hline $\begin{array}{c}\text { OUFTI- } \\
1\end{array}$ & $\begin{array}{c}\text { University } \\
\text { of Liege } \\
\text { Belgium }\end{array}$ & $1 \mathrm{U}$ & $\begin{array}{c}\text { Triple } \\
\text { Junction }\end{array}$ & $\begin{array}{l}\text { Lithium } \\
\text { Polymer }\end{array}$ & $\begin{array}{c}\text { DET Direct } \\
\text { Energy } \\
\text { Transfer }\end{array}$ & $\begin{array}{c}3.3 \mathrm{~V}, 5.0 \mathrm{~V} \\
\text { and } 7.2 \mathrm{~V}\end{array}$ \\
\hline Goliath & $\begin{array}{c}\text { University } \\
\text { of } \\
\text { Bucharest }\end{array}$ & $1 \mathrm{U}$ & $\mathrm{N} / \mathrm{A}$ & $\mathrm{N} / \mathrm{A}$ & $\begin{array}{c}\text { DET } \\
\text { Centralize }\end{array}$ & $3.3 \mathrm{~V}, 5.0 \mathrm{~V}$ \\
\hline $\begin{array}{c}\text { Explore } \\
\text { r } 1 \\
\text { [PRIME } \\
\text { ] } \\
\end{array}$ & $\begin{array}{c}\text { Montana } \\
\text { State } \\
\text { University }\end{array}$ & $1 \mathrm{U}$ & $\mathrm{N} / \mathrm{A}$ & Lithium-ion & $\mathrm{N} / \mathrm{A}$ & $\mathrm{N} / \mathrm{A}$ \\
\hline e-star & $\begin{array}{c}\text { Politecnico } \\
\text { di Torino } \\
\text { Italy } \\
\end{array}$ & $1 \mathrm{U}$ & $\mathrm{N} / \mathrm{A}$ & $\mathrm{N} / \mathrm{A}$ & $\mathrm{N} / \mathrm{A}$ & $\mathrm{N} / \mathrm{A}$ \\
\hline $\begin{array}{c}\text { AAUSA } \\
\mathrm{T}\end{array}$ & $\begin{array}{c}\text { Aalborg } \\
\text { University }\end{array}$ & $1 \mathrm{U}$ & $\mathrm{N} / \mathrm{A}$ & $\begin{array}{l}\text { Lithium-ion } \\
\text { cells }\end{array}$ & MPPT & $5.0 \mathrm{~V}$ \\
\hline Kufasat & $\begin{array}{c}\text { University } \\
\text { of Kufa }\end{array}$ & $1 \mathrm{U}$ & $\begin{array}{c}\text { Hybrid } \\
\text { AzurSpace } \\
\text { TJ }\end{array}$ & $\begin{array}{l}\text { Lithium } \\
\text { Polymer } \\
\text { batteries }\end{array}$ & MPPT & $3.3 \mathrm{~V}, 5.0 \mathrm{~V}$ \\
\hline
\end{tabular}




\begin{tabular}{|c|c|c|c|c|c|c|}
\hline NPSAT1 & $\begin{array}{c}\text { Naval } \\
\text { Postgradua } \\
\text { te School }\end{array}$ & $1 \mathrm{U}$ & $\begin{array}{c}\text { Improved } \\
\text { Triple } \\
\text { junction }\end{array}$ & $\begin{array}{c}\text { Lithium } \\
\text { Polymer } \\
\text { batteries }\end{array}$ & $\begin{array}{c}\text { MPPT } \\
\text { Centralized }\end{array}$ & $3.3 \mathrm{~V}, 5.0 \mathrm{~V}$ \\
\hline $\begin{array}{c}\text { FunCub } \\
\text { e-1 }\end{array}$ & AMSAT-UK & $1 \mathrm{U}$ & $\begin{array}{c}\text { Triple } \\
\text { Junction }\end{array}$ & $\begin{array}{c}\text { Lithium-ion } \\
\text { GOMSpace } \\
\text { Denmark }\end{array}$ & MPPT & $\begin{array}{c}3.3 \mathrm{~V} \text { and } \\
5.0 \mathrm{~V}\end{array}$ \\
\hline $\begin{array}{c}\text { NANOS } \\
\text { ATC- } \\
\text { BR1 }\end{array}$ & $\begin{array}{c}\text { Federal } \\
\text { University }\end{array}$ & $1 \mathrm{U}$ & N/A & N/A & $\begin{array}{c}\text { MPPT } \\
\text { Distributed }\end{array}$ & $\begin{array}{c}3.3 \mathrm{~V} \text { and } \\
5.0 \mathrm{~V}\end{array}$ \\
\hline
\end{tabular}

\section{DESIGN, MODELING AND OPERATION OF ELECTRICAL POWER SUBSYSTEM}

\subsection{Theory and Mathematical Modeling of Triple-Junction Solar Cell}

Performance characteristics of a space grade PV triple-junction solar cell are successfully evaluated using a single-diode model equivalent circuit and analytical modeling in the literature. The theory and evolution of multijunction solar cell have been explained in detail in [10-13], while the methods of modeling of PV cells are given in [10-17].

The triple-junction solar cell is made as stack of three individual subcells having dissimilar parameters of decreasing energy band gap connected together in series with the sub-cell having the lowest band gap. This construction ensures a better absorption of the light spectrum reaching the cell. The triple-junction cell obtains its higher efficiency status to this method of production [10-17]. Fabrication methods of triple-junction solar cells are investigated in [10] and [13]. The solar PV cell is modeled as a current source with an anti-parallel diode to account for reverse saturation and sometimes these reverse saturation and recombination currents are lumped together. Two resistors, one in parallel with the diode(s) and the other in series with them are connected in the model. The one-diode model known as a 5parameter model is addressed in [15] and [18].

Figure 2 shows a one-diode 5-parameter model for a single junction cell whereas three of such cells are connected together to obtain triplejunction solar cell as indicated in Figure 3. 


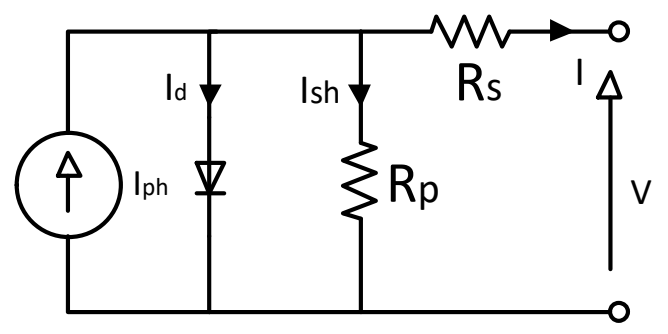

Figure 2. A Generic one-diode model of a solar cell

For the purpose of this modeling and performance evaluation of the mentioned cell type, the AZURSPACE triple-junction solar cell is selected given in [19]. It is assumed that the sub-cells are latticed-matched and therefore providing same current unlike [20] where the minimum current of the group is taken. Because, the study presented in [20] is based on Air Mass (AM) greater than zero. With reference to Figure 3, cell current can be obtained using Kirchhoff's current law as

$I=I_{p h, i} \quad I_{d, i} \quad I_{s h, i}$

where $I$ is the current of the cell, $I_{p h, i}$ is the photo-generated current in the sub-cells, $I_{d, i}$ is the diode current for the sub-cells, and $I_{s h i}$ the current in the shunt branch of each sub-cell, the subscript $i=1,2$, and 3 for the three subcells, respectively. Photo-generated current $I_{p h i}$ is given by

$I_{p h, i}=\left[I_{s c}+k_{I_{s c}}\left(T_{c} \quad T_{r e f}\right)\right] \cdot \frac{G}{G_{r e f}}$

In Equation (2), $I_{s c}$ is the short-circuit current of the cell when opencircuit voltage equals to zero. $k_{I_{S c}}$ is the short-circuit temperature coefficient in $A m p /{ }^{\circ} \mathrm{C}$ and it is a very small value for triple-junction cells and its effect is minimal [21]. $T_{c}$ and $T_{r e f}$ are the operating temperature of the cell, respectively. Reference temperature at standard test conditions (STC) is used as $28^{\circ} \mathrm{C}$. $G_{r e f}$ and $G$ are the reference solar irradiance given as $1367 \mathrm{~W} / \mathrm{m}^{2}$, AM0, at STC and the actual irradiance falling on the cell area, respectively. 


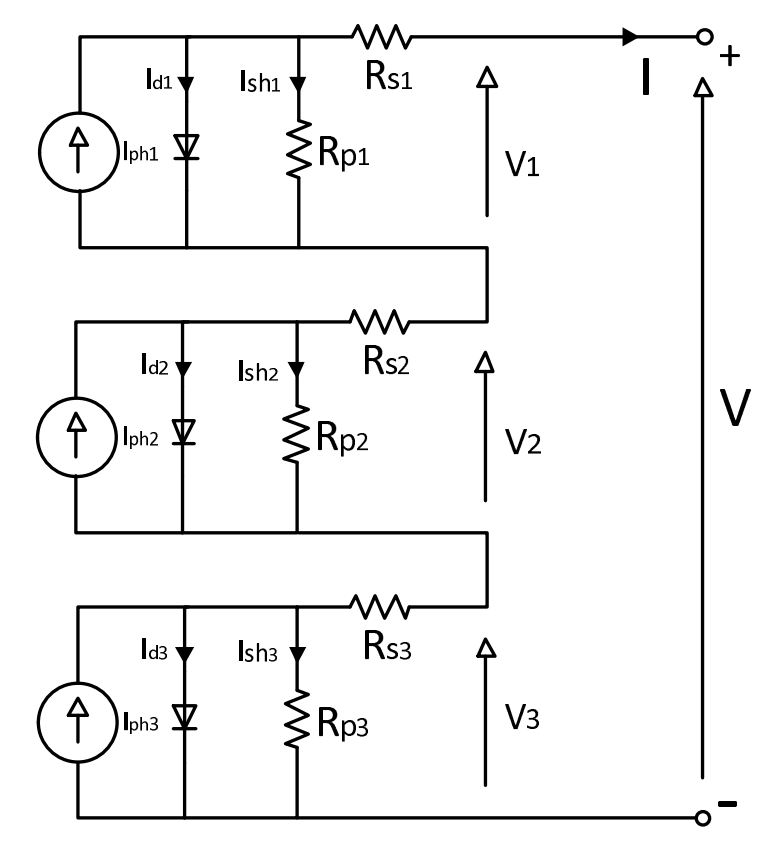

Figure 3. One-diode model of a triple-junction solar cell

$$
\begin{aligned}
& I_{d, i}=I_{o, i} \cdot\left[e^{q \cdot \frac{\left(V+A \cdot I \cdot R_{S, i}\right)}{n_{i} \cdot k_{b} \cdot T_{c}}} \quad 1\right] \\
& I_{o, i}=I_{r s, i} \cdot T_{c}^{\left(\frac{3+\gamma i}{2}\right)} \cdot e^{\frac{-q \cdot E_{g, i}\left(T_{c}\right)}{n_{i} \cdot k_{b} \cdot T_{C}}}
\end{aligned}
$$

The diode current $I_{d, i}$ and $I_{o, i}$ are a function of the lumped reverse saturation and recombination currents $I_{r s, i}$ given as $K_{i}$ for the 5-parameter model. $I_{r s, i}$ is determined usually through measurements given in [11] and [15]. $\gamma_{i}$ is another ideality constant, $E_{g, i}\left(T_{c}\right)$ is the band gap and $n_{i}, k_{b}$, and $q$ are the ideality factor depending on the tunnel junction quality. Boltzmann's constant given by $1.380658 \times 10^{-23} \mathrm{~J} / \mathrm{K}$ and the charge of electron as $1.602 \times 10^{-19} \mathrm{C}$, respectively. $V$ is the voltage at the terminal of the cell. $R_{s, i}$ and $A$ are the series resistances of the sub cells, the effective area of the cell, respectively. From Equation (4), band gap energy $E_{g, i}\left(T_{c}\right)$ is given by the relation

$$
E_{g, i\left(T_{c}\right)}=E_{g, i(0)} \quad \frac{\alpha_{i} T_{c}^{2}}{T_{c}+\beta_{i}}
$$

$E_{g, i(0)}$ in Equation (5) is the measured band gap obtained at temperature of zero Kelvin. $\alpha_{, i}$ and $\beta_{i}$ are all distinct for the semiconductors and directly related to temperature effect. $\alpha_{, i}$ is the energy per Kelvin of the material while $\beta_{i}$ is a fitting parameter for the temperature. Shunt current indicated as $I_{s h, i}$ is given in Equation (6)

$I_{s h, i}=\frac{V+I \cdot A \cdot R_{S, i}}{A \cdot R_{p, i}}$ 
where $R_{p, i}$ is the parallel resistance of the cell and often neglected. Substituting Equations (2), (3), (4), and (6) into equation (1) yields equation (7) known as the output current equation of the cell given as

$$
I=I_{p h, i} \quad I_{o, i}\left[e^{\left(\frac{V+I \cdot A \cdot R_{s, i}}{n \cdot V_{t}}\right)} \quad 1\right] \frac{V+I \cdot A \cdot R_{s, i}}{A \cdot R_{p, i}}
$$

Cell voltage of each sub cell $V_{i}$ extracted from Equation (7) by neglecting the parallel resistance $R_{p}$ seen in [15] and [20] derived in Equation (8)

$$
V_{i}=\frac{n_{i} \cdot k \cdot T_{c}}{q} \cdot \ln \left(\frac{I_{s c, i}}{I_{o, i}}+1\right) \quad I \cdot A \cdot R_{s, i}
$$

The total cell voltage is the summation of the voltages of the sub cells $V_{i}$

$$
V=\frac{k \cdot T_{C}}{q} \cdot\left[n_{1} \cdot \ln \left(\frac{I_{s c, 1}}{I_{o, 1}}+1\right)+n_{2} \cdot \ln \left(\frac{I_{S c, 2}}{I_{o, 2}}+1\right)+n_{3} \cdot \ln \left(\frac{I_{s c, 3}}{I_{o, 3}}+1\right)\right] \quad I \cdot A \cdot R_{S}(9)
$$

Open-circuit voltage $V_{o c, i}$ of each sub cell is shown in Equation (10) and the total $V_{o c}$ of the cell is given in Equation (11)

$$
\begin{aligned}
& V_{o c, i}=\frac{k \cdot T_{C}}{q} \cdot\left[n_{i} \cdot \ln \left(\frac{I_{S c, i}}{I_{o, i}}+1\right)\right] \\
& V_{o c}=\frac{k \cdot T_{C}}{q} \cdot\left[n_{1} \cdot \ln \left(\frac{I_{S c, 1}}{I_{o, 1}}+1\right)+n_{2} \cdot \ln \left(\frac{I_{S c, 2}}{I_{o, 2}}+1\right)+n_{3} \cdot \ln \left(\frac{I_{S c, 3}}{I_{o, 3}}+1\right)\right]
\end{aligned}
$$

Equations (7) and (9) are the output current and voltage equations, in order. Note that

$$
R_{S}=\sum_{i=1}^{3} R s_{i}
$$

Fill factor (FF) is a measurement of qualitative a particular cell

$$
F F=\frac{V_{m p p} \cdot I_{m p p}}{V_{o c} \cdot I_{S C}}
$$

where $V_{m p p}$ is the cell voltage at the maximum power point, and $I_{m p p}$ is the current of the cell. Equation (13) is used to obtain the conversion efficiency $\eta$ of the cell which is shown in Equation (14)

$\eta=\frac{F F \cdot V_{O C} \cdot I_{S C}}{G \cdot A} \times 100 \%$

where $G$ is the solar irradiance received by the cell and $A$ is the area of the cell studied in $m^{2}$ as in [20] and [22]. Another method for calculating the conversion efficiency is explained in [13].

The designed model is implemented using Equation (1)-(14), and these are normally enough to implement the electrical model of the triplejunction solar cell in a simulation tool. 
Table 2. Input values of the fitting parameters necessary to implement the model

\begin{tabular}{|c|c|c|c|c|c|}
\hline Parameter & Value & Parameter & Value & Parameter & Value \\
\hline$E_{g 1(0)}$ & 1.79 & $\gamma_{1}$ & 1.81 & $n_{1}$ & 1.89 \\
\hline$E_{g 2(0)}$ & 1.39 & $\gamma_{2}$ & 1.86 & $n_{2}$ & 1.59 \\
\hline$E_{g 3(0)}$ & 0.68 & $\gamma_{3}$ & 1.44 & $n_{3}$ & 1.43 \\
\hline$K_{i 1}$ & $0.0253 m A /{ }^{\circ} \mathrm{C}$ & $\alpha_{1}$ & $7.5 e^{-4}$ & $K_{1}$ & $1.86 e^{-9}$ \\
\hline$K_{i 2}$ & $0.0005 m A /{ }^{\circ} \mathrm{C}$ & $\alpha_{2}$ & $5.405 e^{-4}$ & $K_{2}$ & $2.195 e^{-7}$ \\
\hline$K_{i 3}$ & $0.0098 m A /{ }^{\circ} \mathrm{C}$ & $\alpha_{3}$ & $4.7774 e^{-4}$ & $K_{3}$ & $10.5 e^{-9}$ \\
\hline$K_{v 1}$ & $6.93 m V /{ }^{\circ} \mathrm{C}$ & $R_{S 1}$ & $0.023 \Omega$ & $T_{r e f}$ & $298.15 \mathrm{k}$ \\
\hline$K_{v 2}$ & $6.2 m V /{ }^{\circ} \mathrm{C}$ & $R_{s 2}$ & $0.0012 \Omega$ & $G_{r e f}$ & $1367 \mathrm{~W} / \mathrm{m}^{2}$ \\
\hline$K_{v 3}$ & $5.6 \mathrm{mV} /{ }^{\circ} \mathrm{C}$ & $R_{s 3}$ & $0.0008 \Omega$ & $\mathrm{I}_{m p p}$ & $504.4 m A$ \\
\hline$\beta_{1}$ & 372 & $R_{p 1}$ & $16 M \Omega$ & $V_{m p p}$ & $2411 m V$ \\
\hline$\beta_{2}$ & 204 & $R_{p 2}$ & $4.5 M \Omega$ & $\mathrm{V}_{o c}$ & $2700 m V$ \\
\hline$\beta_{3}$ & 235 & $R_{p 3}$ & $540 K \Omega$ & $I_{s c}$ & $520.2 m A$ \\
\hline
\end{tabular}

The parameter values used in the simulation are obtained from the datasheet of the solar cell [21]. Input values of the fitting parameters necessary to implement the model using the equations are adopted and presented in Table 2.

Most of the literature cited in this paper are stressed the importance of studying the impact of temperature and irradiance changes on a solar cell. Therefore, it is necessary to investigate these phenomena. The cell used for validation of developed model is reported to have $30 \%$ conversion efficiency and it is tested at AM0 irradiance spectrum at a temperature of $28^{\circ} \mathrm{C}$. In order to study the performance of the cell, model is simulated at the given parameters of the STC. Since the study investigates the performance of a Space grade cell, the temperature range selected is from ( 20 to 100$)^{\circ} \mathrm{C}$ and the irradiance is increased from 200 to $1367 \mathrm{~W} / \mathrm{m}^{2}$ in a step of 200 .

\subsection{Modeling and Control of SEPIC}

SEPIC is a very attractive converter topology because of its very good electro-magnetic interference (EMI) profile since its input current is nonpulsating. Another advantage of using SEPIC is that a simple switch gate drive can be used because the switch is connected to the ground of the circuit. That is, complexity in the gate drive circuit reduces since it has same ground node for the input and output. SEPIC has also a very suitable structure for battery storage applications in devices such as laptop and CubeSat [23-25]. Figure 4 represents the schematic of a SEPIC showing all the active and passive elements used for the design of the $3.3 \mathrm{~V}$ and $5.0 \mathrm{~V}$ power supplies. 


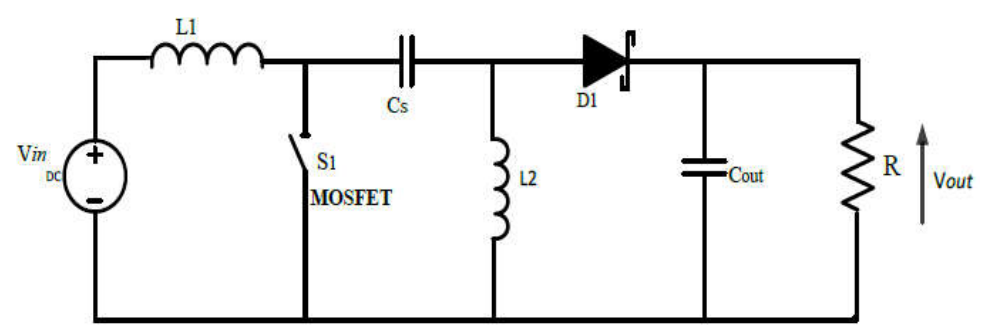

Figure 4. Circuit structure of a SEPIC

SEPIC has two operational states being controlled by the duty cycle " $d$ ". Transfer relationship between input and output of an ideal SEPIC as shown in Equation (15) is given by

$\frac{V_{o}}{V_{\text {in }}}=\frac{d}{1-d}$

It is modeled using state-space equations in current control mode where the inductor current il1 never falls to zero. The equations of the model for switching periods $d T s$ and $\left(\begin{array}{ll}1 & d\end{array}\right) T s$ are obtained. The equations are for the two modes of operations - $d T s$ when $S 1$, is on and $\left(\begin{array}{ll}1 & d\end{array}\right) T s$ when the switch $S 1$ is off. Figure 5(a) shows the ON state of the SEPIC while Figure 5(b) shows the OFF state.

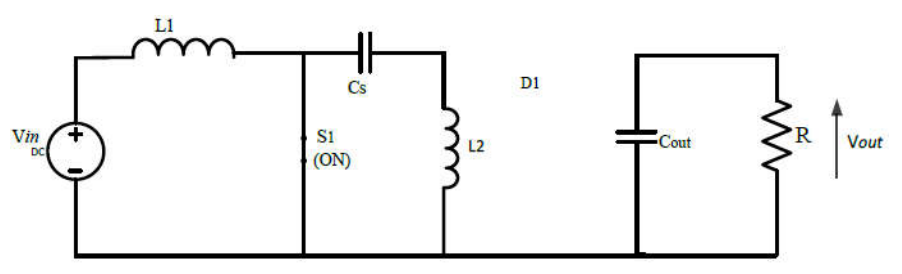

(a)

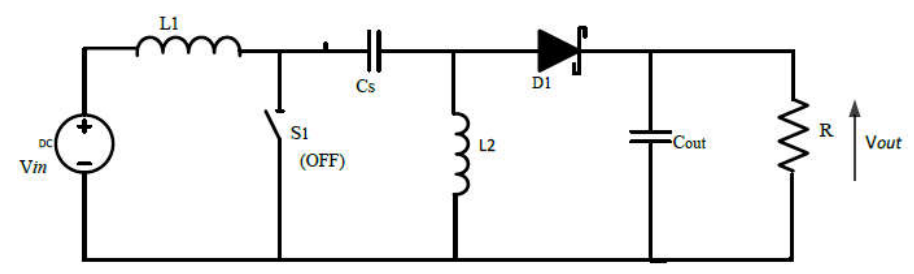

(b)

Figure 5. SEPIC states; (a) ON, (b) OFF 
State-space model is defined as an equation in the form of $[x]=[A][x]+[B][u]$

$[y]=[C][x]+[D][u]$

It is proceed to combine the two states of operation of the converter in to one non-linear equation using the state space averaging (SSA) technique in Equations (12) and (13)

$$
\begin{aligned}
& {[x]=\left[A_{1} \cdot d\right][x]+\left[B_{1} \cdot d\right][u], \text { for } 0<t<d T_{s}} \\
& {[x]=\left[A_{2} \cdot(1 \quad d)\right][x]+\left[B_{2} \cdot(1 \quad d)\right][u] \text {, for } 0<t<\left(\begin{array}{ll}
1 & d
\end{array}\right) T_{s}}
\end{aligned}
$$

The duty cycle weighed-averaged model can be obtained as follows

$$
\begin{aligned}
& {[x]=\left[\left[A_{1} \cdot d\right]+\left[A_{2} \cdot(1 \quad d)\right]\right][x]+\left[\left[B_{1} \cdot d\right]+\left[B_{2} \cdot(1 \quad d)\right]\right][u]} \\
& {\left[V_{o}\right]=\left[\left[C_{1} \cdot d\right]+\left[C_{2} \cdot(1 \quad d)\right]\right][x]+\left[\left[D_{1} \cdot d\right]+\left[D_{2} \cdot(1 \quad d)\right]\right][u]}
\end{aligned}
$$

Equations (19) and (20) are combined as averaged large signal model (ALSM) derived in Equation (21).

$$
\begin{aligned}
& {\left[\begin{array}{c}
l_{l 1} \\
v_{c 1} \\
l_{l 2} \\
v_{c 2}
\end{array}\right]=\begin{array}{cccc}
\frac{-1}{L_{1}} & 0 & 0 & 0 \\
0 & 0 & \frac{1}{C_{1}} & 0 \\
0 & \frac{-1}{L_{2}} & \frac{-1}{L_{2}} & 0 \\
0 & 0 & 0 & \frac{-1}{R C_{2}}
\end{array}\left[\begin{array}{c}
i_{l 1} \\
v_{c 1} \\
i_{l 2} \\
v_{c 2}
\end{array}\right]+\begin{array}{l}
\frac{1}{L_{1}} \\
0 \\
0 \\
0
\end{array}\left[v_{i n}\right]} \\
& {\left[v_{o}\right]=\left[\begin{array}{llll}
0 & 0 & 0 & 1
\end{array}\right]\left[\begin{array}{c}
i_{l 1} \\
v_{c 1} \\
i_{l 2} \\
v_{c 2}
\end{array}\right]+[0]\left[v_{\text {in }}\right]} \\
& \left.\left[\begin{array}{c}
l_{l 1} \\
v_{c 1} \\
l_{l 2} \\
v_{c 2}
\end{array}\right]=\begin{array}{cccc}
\frac{-1}{L_{1}} & \frac{-1}{L_{1}} & 0 & \frac{-1}{L_{1}} \\
\frac{1}{C_{1}} & 0 & 0 & 0 \\
0 & 0 & \frac{-1}{L_{2}} & \frac{1}{L_{2}} \\
\frac{-1}{C_{2}} & 0 & \frac{-1}{C_{2}} & \frac{-1}{R C_{2}}
\end{array}\left[\begin{array}{c}
i_{l 1} \\
v_{c 1} \\
i_{l 2} \\
v_{c 2}
\end{array}\right]+\begin{array}{l}
\frac{1}{L_{1}} \\
0 \\
0 \\
0
\end{array}\right] \\
& {\left[v_{o}\right]=\left[\begin{array}{llll}
0 & 0 & 0 & 1
\end{array}\right]\left[\begin{array}{c}
i_{l 1} \\
v_{c 1} \\
i_{l 2} \\
v_{c 2}
\end{array}\right]+[0]\left[v_{i n}\right]}
\end{aligned}
$$




$$
\begin{aligned}
& \begin{array}{llll}
\frac{-1}{L_{1}} & 0 & 0 & 0
\end{array} \\
& A_{1}=\begin{array}{cccc}
0 & 0 & \frac{1}{C_{1}} & 0 \\
0 & \frac{-1}{L_{2}} & \frac{-1}{L_{2}} & 0
\end{array} \\
& \begin{array}{llll}
0 & 0 & 0 & \frac{-1}{R C_{2}}
\end{array} \\
& \frac{-1}{L_{1}} \quad \frac{-1}{L_{1}} \quad 0 \quad \frac{-1}{L_{1}} \\
& A_{2}=\begin{array}{cccc}
\frac{1}{C_{1}} & 0 & 0 & 0 \\
0 & 0 & \frac{-1}{L_{2}} & \frac{1}{L_{2}}
\end{array} \\
& \frac{-1}{C_{2}} \quad 0 \quad \frac{-1}{C_{2}} \quad \frac{-1}{R C_{2}} \\
& \frac{1}{L_{1}} \\
& {\left[B_{1}\right]=\left[B_{2}\right]=0} \\
& {\left[C_{1}\right]=\left[C_{2}\right]=\left[\begin{array}{llll}
0 & 0 & 0 & 1
\end{array}\right]} \\
& {\left[D_{1}\right]=\left[D_{2}\right]=[0]}
\end{aligned}
$$

Equations (30) and (31) are a realization of Equations (19) and (20) by manipulating Equations (25)-(29). ALSM of the converters is stated below.

$$
\begin{aligned}
& {\left[\begin{array}{l}
l_{l 1} \\
v_{c 1} \\
l_{l 2} \\
v_{c 2}
\end{array}\right]=\left[\begin{array}{cccc}
\frac{1}{L_{1}} & \frac{d-1}{L_{1}} & 0 & \frac{d-1}{L_{1}} \\
\frac{1-d}{C_{1}} & 0 & \frac{d}{C_{1}} & 0 \\
0 & \frac{-d}{L_{2}} & \frac{-1}{L_{2}} & \frac{1-d}{L_{2}} \\
\frac{1-d}{C_{2}} & 0 & \frac{d-1}{C_{2}} & \frac{-1}{R C_{2}}
\end{array} \cdot\left[\begin{array}{c}
i_{l 1} \\
v_{c 1} \\
i_{l 2} \\
v_{c 2}
\end{array}\right]+\begin{array}{c}
\frac{1}{L_{1}} \\
0 \\
0 \\
0
\end{array}\right]\left[v_{i n}\right]} \\
& {\left[v_{o}\right]=\left[\begin{array}{llll}
0 & 0 & 0 & 1
\end{array}\right]\left[\begin{array}{c}
i_{l 1} \\
v_{c 1} \\
i_{l 2} \\
v_{c 2}
\end{array}\right]}
\end{aligned}
$$

To obtain the steady-state and small-signal models of the converter, derivative terms in Equation (30) are set to zero. All other variables are set to steady-state values. Therefore $x=0, i_{l 1}, v_{c 1}, i_{l 2}, v_{c 2},=I_{l 1}, V_{c 1}, I_{l 2}, V_{c 2}, d=D, v_{i n}=V_{i n}, v_{o}=V_{o}$.

Steady-state model is expressed in Equations (32) and (33) 


$$
\begin{aligned}
& {\left[\begin{array}{l}
0 \\
0 \\
0 \\
0
\end{array}\right]=\left[\begin{array}{cccc}
\frac{1}{L_{1}} & \frac{D-1}{L_{1}} & 0 & \frac{D-1}{L_{1}} \\
\frac{1-D}{C_{1}} & 0 & \frac{D}{C_{1}} & 0 \\
0 & \frac{-D}{L_{2}} & \frac{-1}{L_{2}} & \frac{1-D}{L_{2}} \\
\frac{1-D}{C_{2}} & 0 & \frac{D-1}{C_{2}} & \frac{-1}{R C_{2}}
\end{array} \cdot\left[\begin{array}{l}
I_{l 1} \\
V_{c 1} \\
I_{l 2} \\
V_{c 2}
\end{array}\right]+\begin{array}{c}
\frac{1}{L_{1}} \\
0 \\
0 \\
0
\end{array} .\left[V_{i n}\right]\right.} \\
& {\left[V_{o}\right]=\left[\begin{array}{llll}
0 & 0 & 0 & 1
\end{array}\right]\left[\begin{array}{c}
I_{l 1} \\
V_{c 1} \\
I_{l 2} \\
V_{c 2}
\end{array}\right]}
\end{aligned}
$$

Small signal model of the converter is obtained using the ALSM and by applying a perturbation around the steady-state variables of the model where $x=X+\hat{x}$

$d=D+\hat{d} v_{o}=V_{o}+\hat{v}_{o}, v_{i n}=V_{\text {in }}+\hat{v}_{\text {in }}$ are inserted in Equation (32) as given in Equation (34), then, small signal model is extracted by multiplying the steady-state parts and disturbance around the steady-state.

$$
\left[\begin{array}{c}
I_{l 1}+l_{l 1} \\
V_{c 1}+v_{c 1} \\
I_{l 2}+l_{l 2} \\
V_{c 2}+v_{c 2}
\end{array}\right]=\begin{array}{cccc}
\frac{1}{L_{1}} & \frac{D-1+\hat{d}}{L_{1}} & 0 & \frac{D-1+\hat{d}}{L_{1}} \\
\frac{1-D-\hat{d}}{C_{1}} & 0 & \frac{D+\hat{d}}{C_{1}} & 0 \\
0 & \frac{-D-\hat{d}}{L_{2}} & \frac{-1}{L_{2}} & \frac{1-D-\hat{d}}{L_{2}} \\
\frac{1-D-\hat{d}}{C_{2}} & 0 & \frac{D-1+\hat{d}}{C_{2}} & \frac{-1}{R C_{2}}
\end{array} \cdot\left[\begin{array}{c}
I_{l 1}+l_{l 1} \\
V_{c 1+} \hat{v}_{c 1} \\
I_{l 2}+l_{l 2} \\
V_{c 2+} \hat{v}_{c 2}
\end{array}\right]+\begin{gathered}
\frac{1}{L_{1}} \\
0 \\
0 \\
0
\end{gathered} .\left[V_{i n}+\hat{v}_{i n}\right]
$$

Extracted complete small signal part is described in Equation (35), however, an output current $l_{z}$ term is added to the model for current control.

$$
\left[\begin{array}{c}
l_{l 1} \\
\hat{v}_{c 1} \\
l_{l 2} \\
\hat{v}_{c 2}
\end{array}\right]=\left[\begin{array}{cccc}
\frac{1}{L_{1}} & \frac{D-1}{L_{1}} & 0 & \frac{D-1}{L_{1}} \\
\frac{1-D}{C_{1}} & 0 & \frac{D+\hat{d}}{C_{1}} & 0 \\
0 & \frac{-D}{L_{2}} & \frac{-1}{L_{2}} & \frac{1-D}{L_{2}} \\
\frac{1-D}{C_{2}} & 0 & \frac{D-1+\hat{d}}{C_{2}} & \frac{-1}{R C_{2}}
\end{array} \cdot\left[\begin{array}{c}
l_{l 1} \\
\hat{v}_{c 1} \\
l_{l 2} \\
\hat{v}_{c 2}
\end{array}\right]+\begin{array}{ccc}
\frac{i_{l_{1}+v_{c 2}}}{L_{1}} & \frac{1}{L_{1}} & 0 \\
\frac{i_{l 2}+i_{l 1}}{C_{1}} & 0 & 0 \\
\frac{-v_{c 1}-v_{c 2}}{L_{2}} & 0 & 0 \\
\frac{i_{l 2}-i_{l 1}}{C_{2}} & 0 & \frac{-1}{C_{2}}
\end{array} \cdot\left[\begin{array}{c}
\hat{d} \\
\hat{v}_{i n} \\
l_{z}
\end{array}\right]\right.
$$

From (32), it can be obtained line-to-output transfer function of the plant $\frac{v_{0}}{v_{\text {in }}}$ while Equation (35) would produce three transfer functions for the controlto-output $\frac{\widehat{v}_{0}}{\widehat{d}} @ \hat{v}_{\text {in }}=l_{z}=0$. Small signal line-to-output $\frac{\widehat{v}_{0}}{\widehat{v}_{\text {in }}} @ \hat{\mathrm{d}}=\mathrm{l}_{\mathrm{z}}=0$. Small signal output impedance $\frac{\widehat{v}_{\mathrm{o}}}{\mathrm{l}_{\mathrm{z}}}$ evaluated @ $\mathrm{d}=\hat{\mathrm{v}}_{\mathrm{in}}=0$. Equations (32), (33) and (34) are employed for the controller design. 


\subsubsection{Power Stage Design of SEPIC}

There are several methods of design calculations for SEPIC, however, design guides given by Texas Instruments in $[26,27]$ are adopted and design equations are presented as follows. $\mathrm{V}_{\text {out1 }}=3.3 \mathrm{~V}, \mathrm{~V}_{\text {out2 }}=5.0 \mathrm{~V}$ (output voltages), $\quad \mathrm{V}_{\mathrm{in}, \min }=3.0 \mathrm{~V}, \mathrm{~V}_{\mathrm{in}, \max }=4.2 \quad$ (input voltage range), $\mathrm{I}_{\text {out1 }}=$ $2.5 \mathrm{Amp}, \mathrm{I}_{\text {out } 2}=2.0 \mathrm{Amp}, \mathrm{F}_{\mathrm{sw}}=1 \mathrm{MHz}$ (switching frequency), $\mathrm{V}_{\mathrm{d}}=0.3$ (forward voltage of Schottky diode). Equation (37) and (38) are the formulas for calculating the maximum and minimum duty cycles, respectively.

$$
\begin{aligned}
& D_{\text {max }}=\frac{V_{\text {out }}+V_{d}}{V_{\text {in,min }}+V_{\text {out }}+V_{d}} \\
& D_{\text {min }}=\frac{V_{\text {out }}+V_{d}}{V_{\text {in,max }}+V_{\text {out }}+V_{d}}
\end{aligned}
$$

Table 3. Circuit parameter values of SEPIC

\begin{tabular}{|c|c|c|}
\hline Components/Variables & 3.3V Converter & 5.0V converter \\
\hline$L_{1}=L_{2}$ & $\begin{array}{c}3.3 \mu \mathrm{H}, 4.7 \mu \mathrm{H} \\
\text { selected }\end{array}$ & $\begin{array}{c}3.0 \mu \mathrm{H}, 4.7 \mu \mathrm{H} \\
\text { selected }\end{array}$ \\
\hline$C_{1}$ & $10 \mu \mathrm{F}$ & $10 \mu \mathrm{F}$ \\
\hline$C_{2}$ & $>68 \mu \mathrm{F}$ & $>42 \mu \mathrm{F}$ \\
\hline$V_{d}$ & $0.3 \mathrm{~V}$ & $0.3 \mathrm{~V}$ \\
\hline$V_{\text {out }}$ & $3.3 \mathrm{~V}$ & $5.0 \mathrm{~V}$ \\
\hline$V_{\text {in,min }}$ & $3.0 \mathrm{~V}$ & $3.0 \mathrm{~V}$ \\
\hline$V_{\text {in,max }}$ & $4.2 \mathrm{~V}$ & $4.2 \mathrm{~V}$ \\
\hline$D_{\max }$ & 0.545 & 0.638 \\
\hline$D_{\min }$ & 0.461 & 0.557 \\
\hline$\Delta V_{C 1}$ & $13.6 \%$ & $12.7 \%$ \\
\hline$I_{\text {out }}$ & $2.5 \mathrm{Amp}$. & $2.0 \mathrm{Amp.}$ \\
\hline$V_{\text {out } \text { min }}$ & $3.29 \mathrm{~V}$ & $4.89 \mathrm{~V}$ \\
\hline$V_{\text {out } \text { max }}$ & $3.34 \mathrm{~V}$ & $5.05 \mathrm{~V}$ \\
\hline
\end{tabular}

\subsubsection{Controller Design of SEPIC}

Figure 6 is the closed-loop control arrangement of the SEPIC with PI controller including the reference and output voltage. It is a feedback controller system used for the converters control.

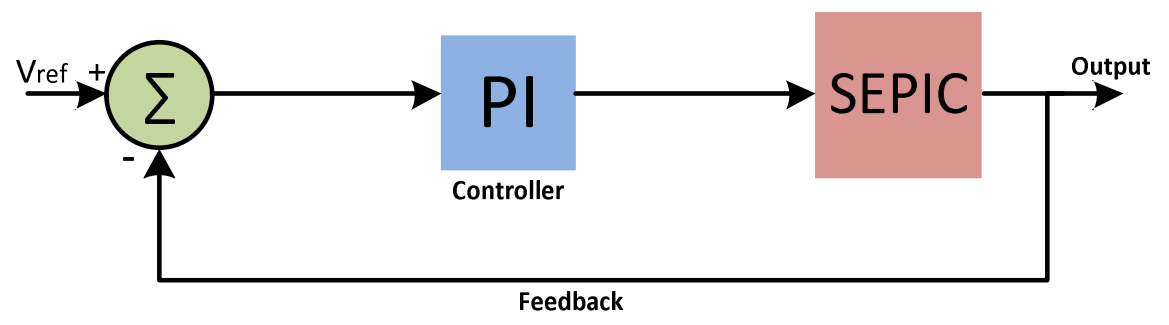

Figure 6. Closed-loop control scheme of the SEPIC 
The controllers for $3.3 \mathrm{~V}$ and 5.0V converters are designed from the state-space model equations. However, both SEPIC and controller transfer functions are fourth order equations, which makes them difficult to implement. SEPICs transfer functions are shown in Equations (39) and (40) for the two converters, respectively.

$$
\begin{aligned}
& \text { Sepic }_{3.3 V}=\frac{1.79 \times 10^{9} s^{2}+3.892 \times 10^{14} s+1.712 \times 10^{19}}{s^{4}+4.34 \times 10^{5} s^{3}+6.029 \times 10^{10} s^{2}+2.833 \times 10^{15} s+2.179 \times 10^{19}} \\
& \text { Sepic }_{5.0 V}=\frac{9.40 \times 10^{8} s^{2}+2.001 \times 10^{14} s+1.117 \times 10^{19}}{s^{4}+4.255 \times 10^{5} s^{3}+5.68 \times 10^{10} s^{2}+2.47 \times 10^{15} s+8.84 \rtimes 10^{18}}
\end{aligned}
$$

Output transfer functions are stated in Equations (41)-(44) for the two converters.

$$
\begin{aligned}
& G_{d v, 3.3 V}=\frac{4.85 \times 10^{4} s^{3}+4.693 \times 10^{10} s^{2}+8.313 \times 10^{15} s+3.91 \times 10^{20}}{s^{4}+4.25 \times 10^{5} s^{3}+5.802 \times 10^{10} s^{2}+2.714 \times 10^{15} s+2.08 \otimes 10^{19}} \\
& G_{d v r, 3.3 V}=\frac{4.76 \otimes 10^{4} s+3.76 \times 10^{10}}{s^{2}+2.205 \times 10^{5} s+2.009 \times 10^{9}} \\
& G_{d v, 5.0 V}=\frac{5.302 \times 10^{4} s^{3}+4.04 \times 10^{10} s^{2}+6.775 \times 10^{15} s+3.118 \times 10^{20}}{s^{4}+4.25 \times 10^{5} s^{3}+5.68 \times 10^{10} s^{2}+2.47 \times 10^{15} s+8.84 \times 10^{18}} \\
& G_{d v r, 5.0 V}=\frac{5.243 \times 10^{4} s+3.001 \times 10^{10}}{s^{2}+2.207 \times 10^{5} s+8.51 \times 10^{8}}
\end{aligned}
$$

\section{SIMULATION RESULTS}

\subsection{Triple-Junction PV Cell Simulation Results}

To evaluate the performance of the cell, main variables are considered as $I_{s c}, V_{o c}, I_{m p p}, V_{m p p}, P_{m p p}, F F$, and efficiency $\eta$. In addition, the effect of temperature change on the band gap energy is taken into account since it is a very important part of the model equations. All variables are temperature dependent which can greatly affect the $V_{m p p}$ and $P_{m p p}$ as can be seen from the $\mathrm{I}-\mathrm{V}$ and $\mathrm{P}-\mathrm{V}$ characteristics curves of the cell.

Table 4. Comparison of datasheet and simulation results at STC

\begin{tabular}{|c|c|c|c|}
\hline Parameters & Datasheet values & Simulated values & Percentage Error \\
\hline$I_{m p p}(m A)$ & 504.4 & 500.2 & $0.8 \%$ \\
\hline$V_{m p p}(m V)$ & 2411 & 2392 & $0.7 \%$ \\
\hline$P_{m p p}(W)$ & 1.216 & 1.196 & $1.644 \%$ \\
\hline$V_{c c}(m V)$ & 2700 & 2659 & $1.518 \%$ \\
\hline$I_{s c}(m A)$ & 520.2 & 520.3 & $0.019 \%$ \\
\hline
\end{tabular}


Table 4 is a summary of the performance of the cell at STC. It can be seen from the simulated values that the model has valid results. Simulation results is verified with the given datasheet performance of the cell under same conditions. However, it is noticed that small increment in the shortcircuit current is occurred higher than the given value in the datasheet.

$\mathrm{I}-\mathrm{V}$ and $\mathrm{P}-\mathrm{V}$ characteristics curves for the individual solar sub-cells at STC extracted from the results are shown in Figures 7 and 8. According to the curves, the "knee" of the curves exists in their maximum points, which are called as "maximum power points" for the individual sub-cells. The lower sub-cell Ge, middle sub-cell GaAs and top cell GaInP produce an open-circuit voltage of $0.2614 \mathrm{~V}, 1.352 \mathrm{~V}$, and $1.289 \mathrm{~V}$, respectively. The total sum of opencircuit voltages goes up to $2.9024 \mathrm{~V}$ while it is $2.7 \mathrm{~V}$ in the datasheet, so, percentage error is around $7.5 \%$. Maximum power points are depicted in Figure 8.

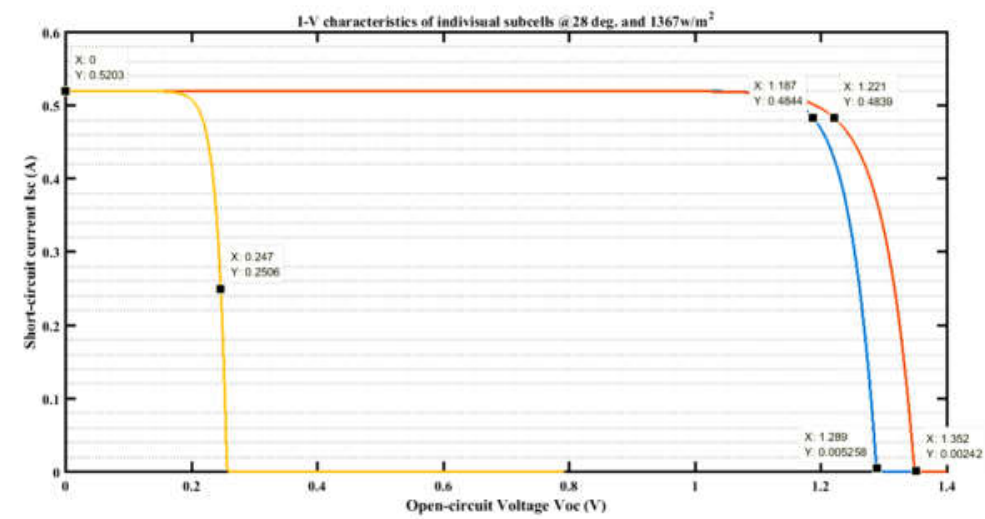

Figure 7. I-V characteristics curves of the sub-cells

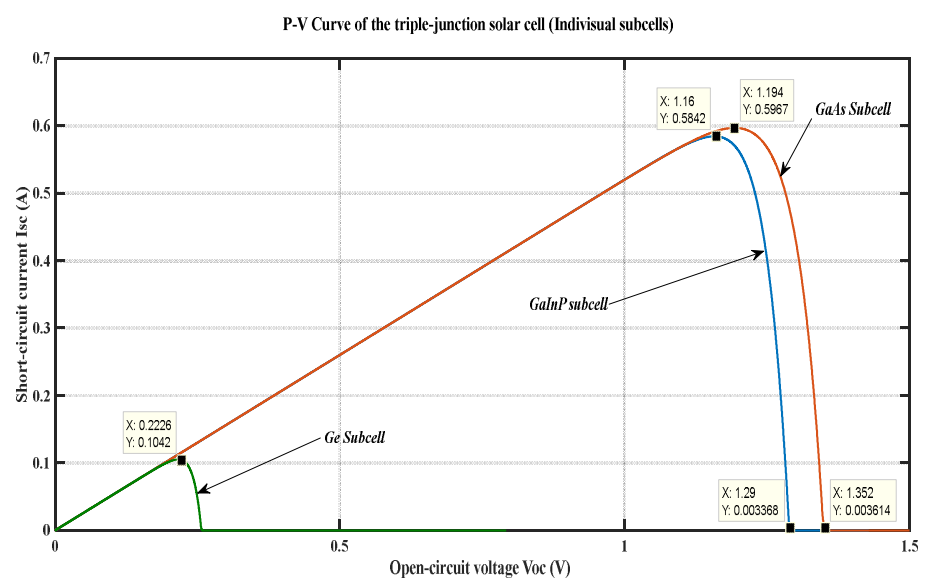

Figure 8. P-V characteristics curves of the sub-cells 
Figure 9 is the I-V characteristics curve of the solar cell plotted from the results. The shaded area represents the cell quality. Voltage at maximum power $V_{m p p}$ is equal to $2.392 \mathrm{~V}$ and the current $I_{m p p}$ stands at $0.5002 \mathrm{~A}$. Maximum power $P_{m p p}$ can be read from Figure 10 as $1.196 \mathrm{~W}$ while the calculated value from the datasheet is equal to $1.2 \mathrm{~W}$. Simulation results show that the designed model is well-done.

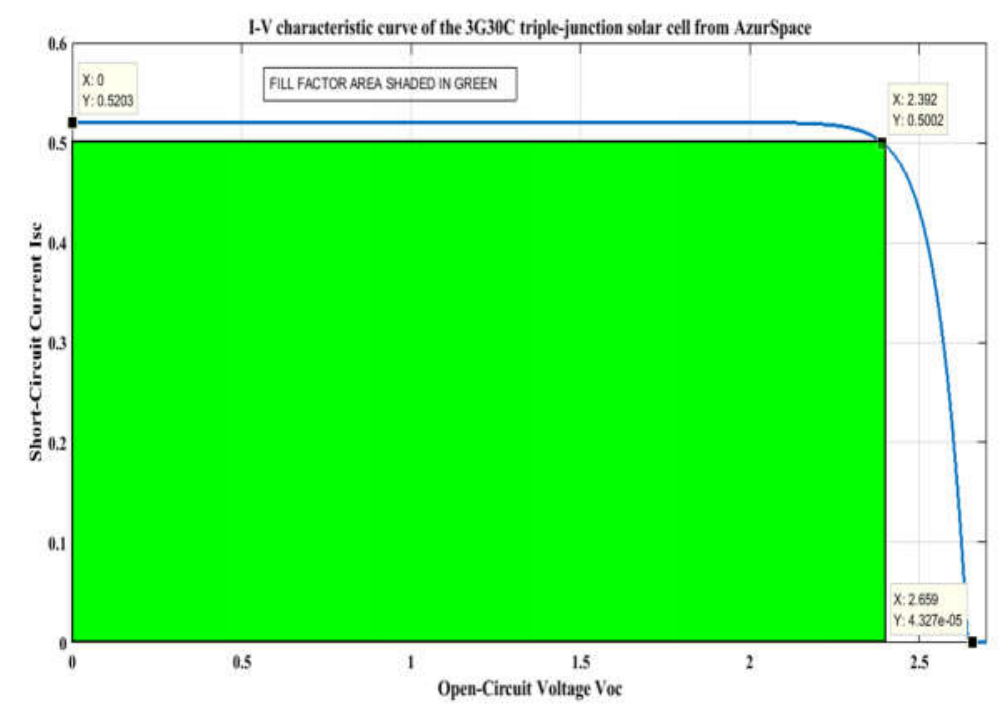

Figure 9. I-V characteristics of the triple-junction solar cell

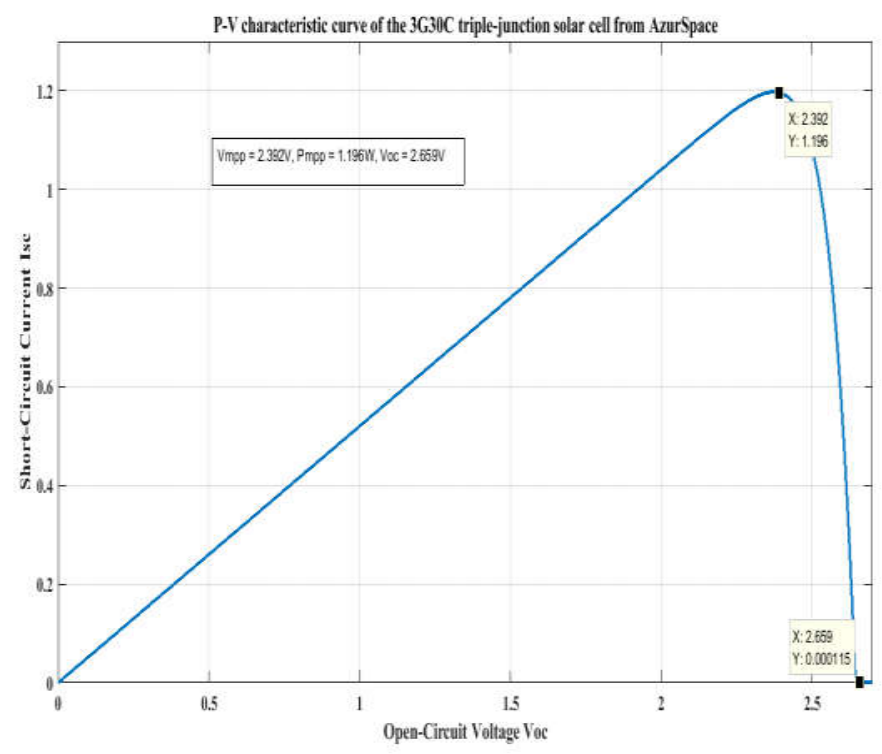

Figure 10. P-V characteristic curve of the Triple-Junction solar cell at STC

FF of the simulated cell (green area in Figure 9) is calculated in accordance with Equation (13) 
$F F=\frac{V_{m p p} \cdot I_{m p p}}{V_{o c} \cdot I_{s c}}$

$\mathrm{FF}$ is calculated to be $0.852(85.2 \%)$. However, calculated FF is 0.8658 $(86.58 \%)$ and a percentage error is $1.59 \%$. Efficiency calculated from Equation (14) as

$\eta=\frac{0.85 \times 2.7 \times 0.5202}{136 \times 0.003018} \times 100 \%=29.0058 \%$

According to the datasheet, average efficiency at $1367 \mathrm{~W} / \mathrm{m}^{2}$ is $29.5 \%$. But, simulated efficiency from designed model is $29 \%$. It can be confidently said that datasheet values and simulation results are mostly confirmed because the error is only $1.675 \%$. The cell operating temperature has effect on the band gap. As the temperature increase, the band gap energy and open-circuit voltage decreases. The band gap Equation (5) is reproduced as

$$
E_{g, i\left(T_{c}\right)}=E_{g, i(0)} \frac{\alpha_{i} T_{c}{ }^{2}}{T_{c}+\beta_{i}}
$$

By varying the operating temperature of the cell from $(-20$ to 100$){ }^{\circ} \mathrm{C}$, band gap energy changes from (1.79 to 1.6499$) \mathrm{eV}$ in the top cell (GaInP), from (1.39 to 1.2597$) \mathrm{eV}$ in the middle cell (GaAs), and from (0.68 to 0.5708 ) in the bottom sub cell (Ge), in order. Table 5 exhibits the effect of temperature increase on the band gap energy of the triple-junction sub-cells.

Table 5. Change of band bap energy with change in temperature $\left({ }^{\circ} \mathrm{C}\right.$ with $\left.\mathrm{eV}\right)$

\begin{tabular}{|l|c|c|c|}
\hline Tem & $E_{\boldsymbol{g}} \boldsymbol{G a I n P}(1.79)$ & $E_{\boldsymbol{g}} \boldsymbol{G a A s}(1.39)$ & $E_{\boldsymbol{g}} \boldsymbol{G e}(0.68)$ \\
\hline 20 & 1.7132 & & \\
\hline 0 & 1.7033 & 1.3143 & 0.6174 \\
\hline 20 & 1.6932 & 1.3055 & 0.6100 \\
\hline 25 & 1.6906 & 1.2966 & 0.6024 \\
\hline 28 & 1.6890 & 1.2944 & 0.6005 \\
\hline 40 & 1.6827 & 1.2930 & 0.5993 \\
\hline 60 & 1.6720 & 1.2876 & 0.5947 \\
\hline 80 & 1.6611 & 1.2784 & 0.5868 \\
\hline 100 & 1.6499 & 1.2691 & 0.5788 \\
\hline
\end{tabular}

Figure 11 is the I-V characteristics curve of the cell showing how the parameters $V_{o c}$ and $I_{s c}$ vary with increment in operating temperature from (20 to 100$){ }^{\circ} \mathrm{C}$. The $I_{s c}$ varies from 0.483 to $0.5743 \mathrm{~A}$ as the cell operating temperature is increased up to $100{ }^{\circ} \mathrm{C}$ from $-20^{\circ} \mathrm{C}$. On the other hand, the open-circuit voltage is varied from $2.682 \mathrm{~V}$ to $2.598 \mathrm{~V}$ between $-20^{\circ} \mathrm{C}$ and $100^{\circ} \mathrm{C}$. 


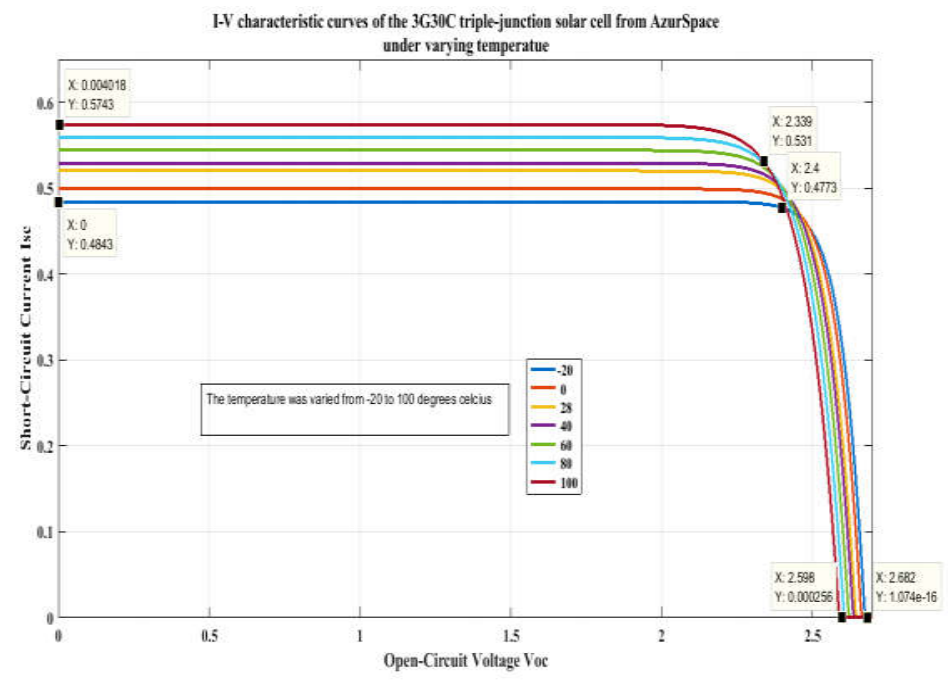

Figure 11 . I-V characteristics of triple-junction solar cell under fixed irradiance and varying temperature

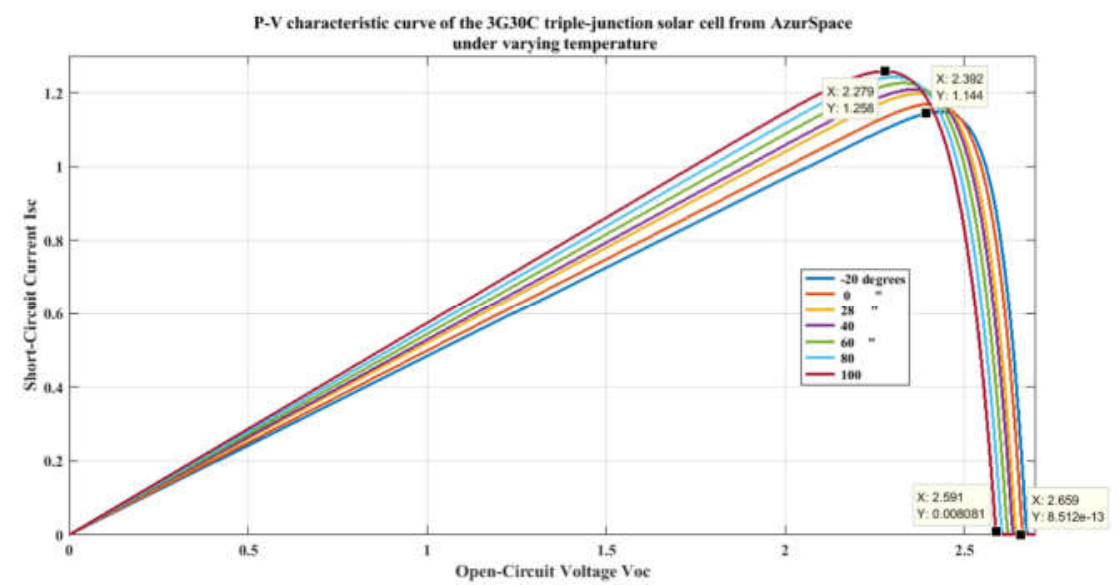

Figure 12. P-V characteristics curve of triple-junction cells under varying temperature

In Figure 12, it is presented the plot of the P-V characteristics curve under same conditions of temperature variations. The maximum voltage and maximum power are recorded as $2.306 \mathrm{~V}$ and $1.255 \mathrm{~W}$ at $100^{\circ} \mathrm{C}$ while they are recorded as $2.446 \mathrm{~V}$ and $1.148 \mathrm{~W}$ at $-20^{\circ} \mathrm{C}$. Figure 13 and 14 demonstrate the I-V and P-V characteristics curves describing the performance of the cell under various irradiance conditions. 


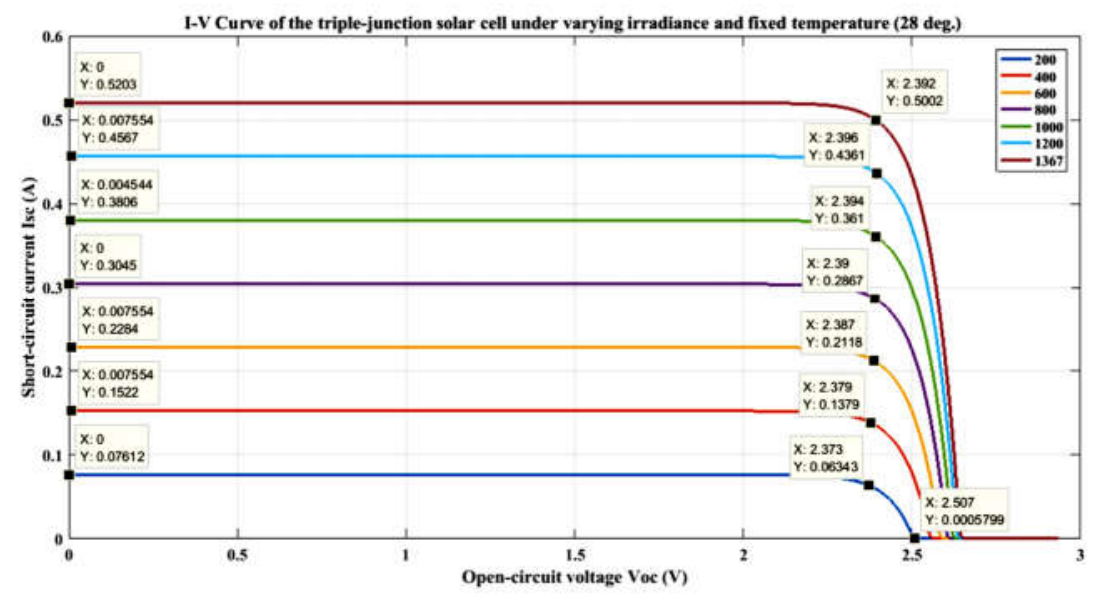

Figure 13. I-V curve of the cell under fixed temperature of $28^{\circ} \mathrm{C}$ and varying irradiance

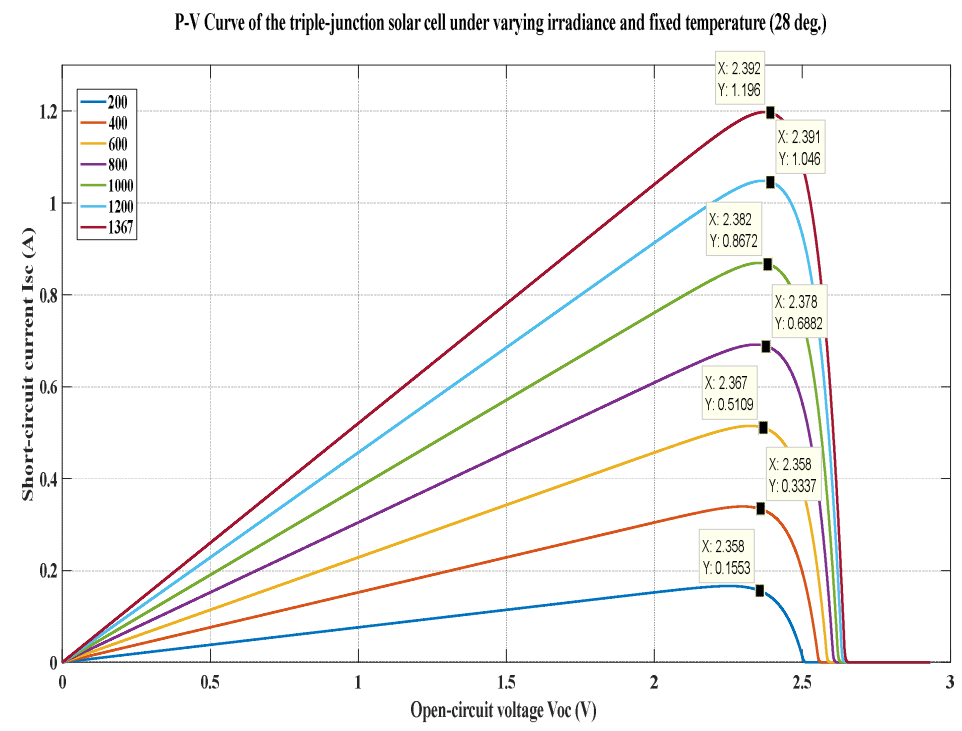

Figure 14. P-V curve of the cell under fixed temperature of 28 degrees and varying irradiance

\subsection{SEPICs Simulation Results}

3.3 $\mathrm{V}$ and $5 \mathrm{~V}$ SEPIC topologies are simulated and the results are found to be quite satisfactory. Figure 15 and 16 present the output voltage and current curves of the $3.3 \mathrm{~V}$ and $5.0 \mathrm{~V}$ converters, respectively. All results are within the limits specified in Table 3. 


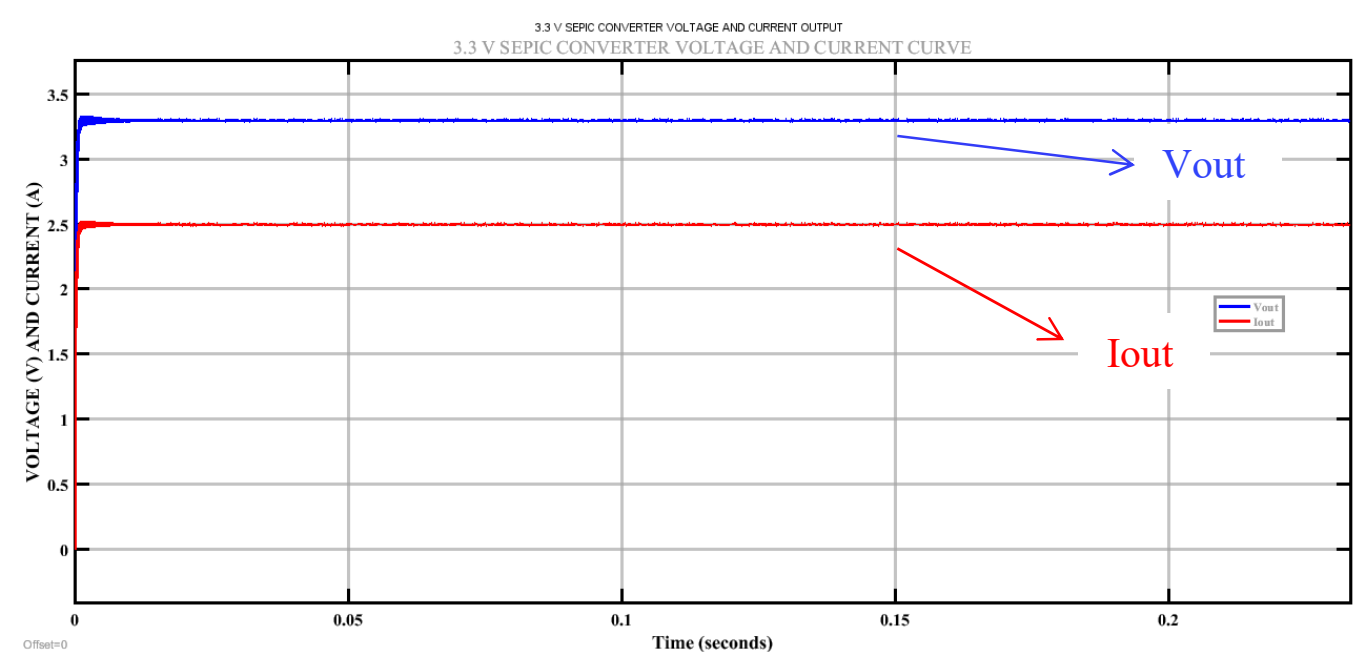

Figure 15. The voltage and current curves of the 3.3V SEPIC

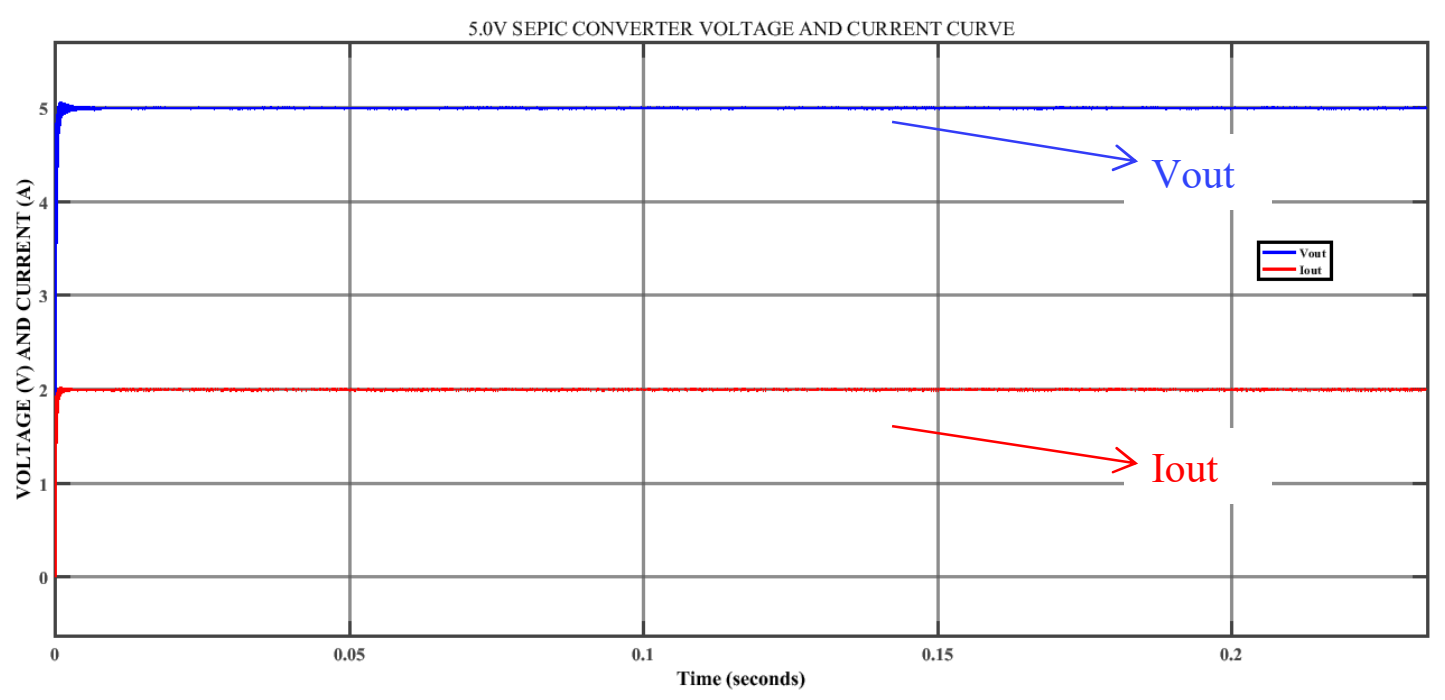

Figure 16. The voltage and current curves of the 5V SEPIC

Controller design for a fourth-order system is a very difficult task; therefore, a suitable way of reducing the models to second-order is employed. The step response of the original fourth-order and the reduced second-order models are compared. The reduced order models are able to represent the original models successfully. Figure 17 shows the step response of the systems both the original and the reduced system of the 3.3V converter. The new step response using the suitable PI coefficients is shown in Figure 18. 


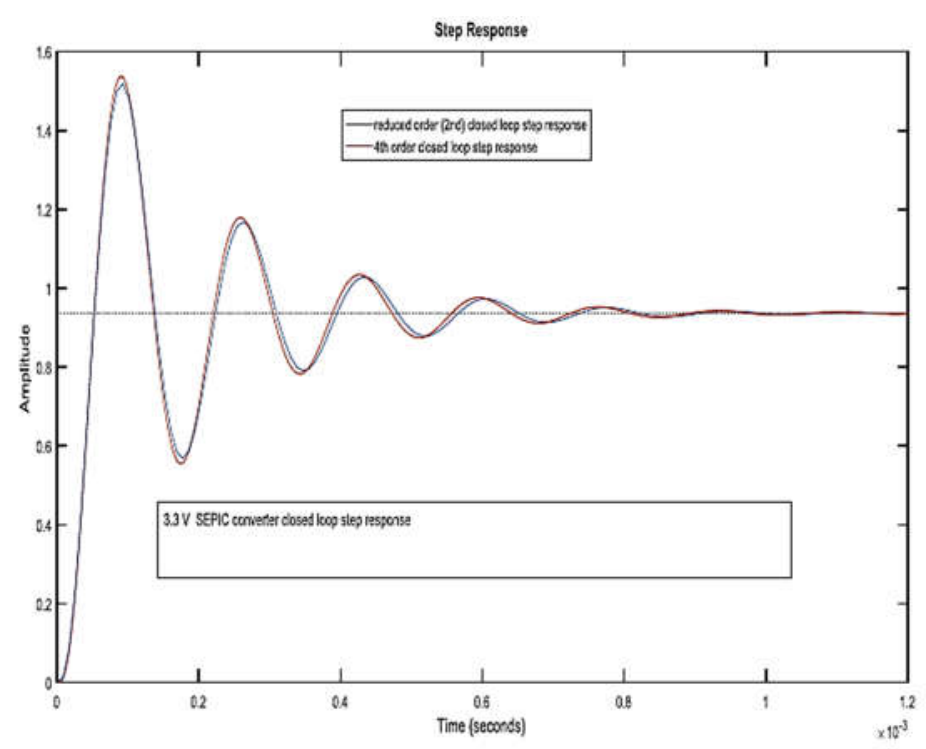

Figure 17. Closed loop original and reduced order step response of the 3.3V SEPIC

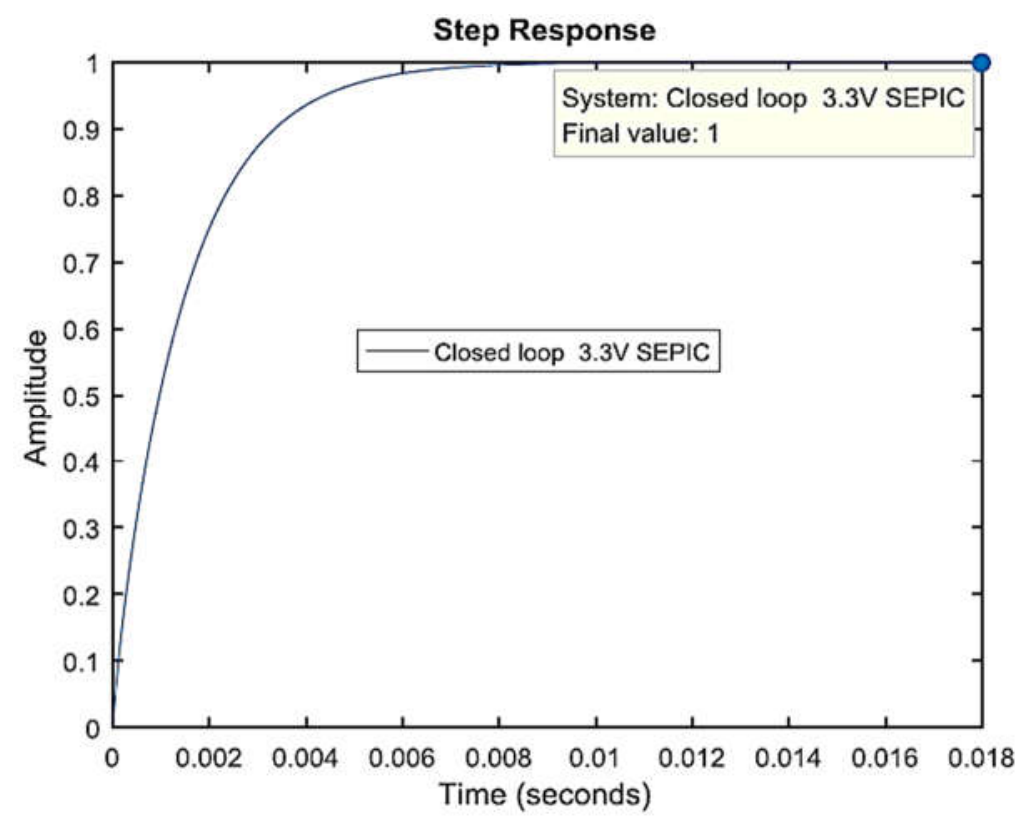

Figure 18. Closed-loop step response of the 3.3V SEPIC

For the 5.0V SEPIC, Figure 19 and 20 show the step response of both the calculated and the tuned PI controller. 


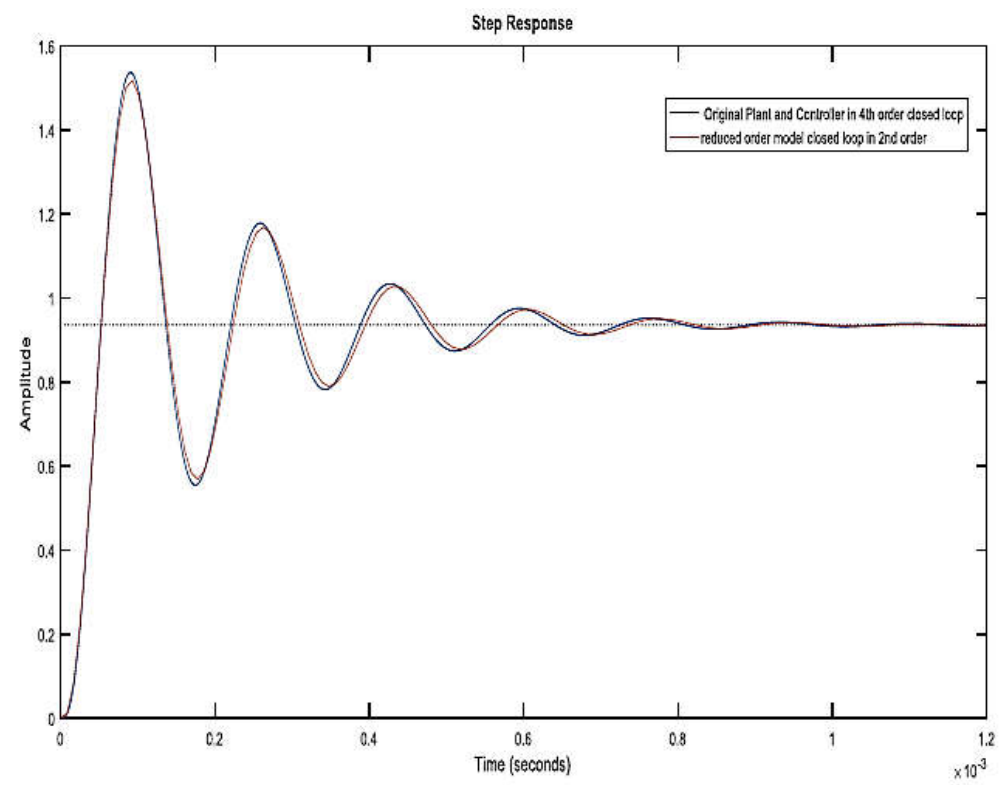

Figure 19. Tuned step response of the closed loop 5.0V converter

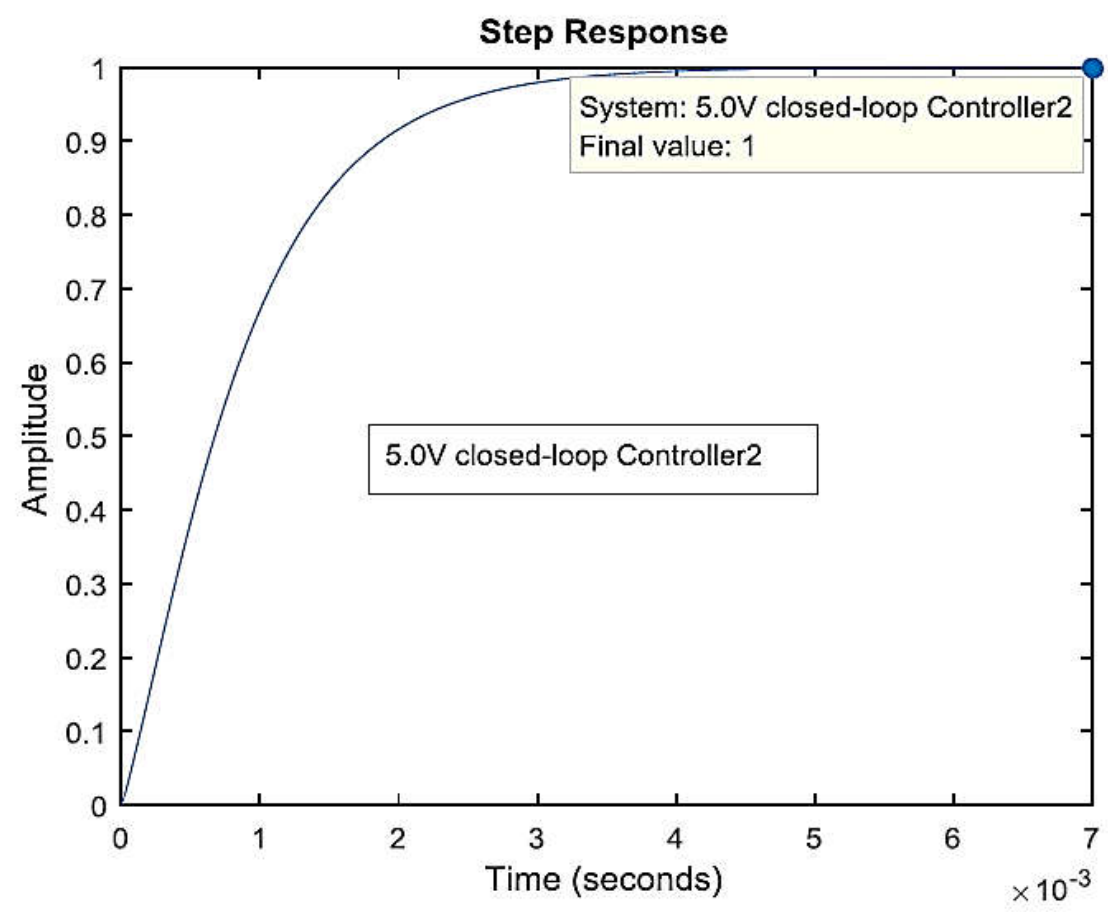

Figure 20. Step response of closed-loop 5.0V converter

\section{DISCUSSION}

Voltage and current output characteristic of the converters are quite promising. In this context, to show the performance of the designed system, a comparison study is carried out in Table 6 with the output voltage profiles of the two famous satellite kits manufacturers called as GOMspace and Endurosat. 
Table 6. Comparison of converter output voltage with those of manufacturers

\begin{tabular}{|c|rl|cc|cc|}
\hline Voltage (V) & \multicolumn{2}{|c|}{ Designed Converter } & \multicolumn{2}{c|}{ Endurosat [28] } & \multicolumn{2}{c|}{ GOMspace [29] } \\
\hline 3.3 & 3.294 & 3.306 & 3.3 & 3.45 & 3.29 & 3.45 \\
\hline 5.0 & 4.994 & 5.006 & 4.88 & 5.15 & 4.89 & 5.05 \\
\hline
\end{tabular}

Comparison in Table 6 gives confidence to accept the result of designed converters modeling, controller design and simulation. However, it is worthy of note that the converter design are performed with ideal components, therefore, it cannot be drawn final conclusions for their superiority over others. Further studies and analysis should be performed.

\section{CONCLUSION}

An EPS for a conceptual $1 \mathrm{U}$ CubeSat mission has been designed by thorough evaluation of performance of the building blocks of the EPS. The functionalities and requirements of the EPS have been clearly spelt out from the onset. Mathematical modeling of the basic elements of the EPS has been provided and design parameters have been also obtained. Triple-junction solar PV cell results have been validated by comparing with the datasheet values. Analysis and performance assessment of designed $3.3 \mathrm{~V}$ and $5 \mathrm{~V}$ SEPIC have been conducted with good results. Output voltages of the both converters have been compared to the reported similar converters by leading manufacturers of such power supplies. Another important conclusion is that similar CubeSat mission EPSs can be developed without necessarily having to conduct extensive literature survey thanks to this work.

\section{REFERENCES}

[1] Cal Poly SLO., CubeSat Design Specification Rev. 12, The CubeSat Program, California State Polytechnic University (California), 2009.

[2] Sellers J.J., Astore W.J., Giffen R.B. and Larson W.J., Understanding Space: an Introduction to Astronautics, McGraw Hill (New York), 3rd edition, 2000.

[3] Craig Clark, Alejandro Lopez Mazarias, Power System Challenges for Small Satellite Missions, Proceedings of the 2006 Small Satellites, Systems and Services Symposium, D. Danesy, Ed. The Netherlands: ESA, 2006.

[4] Sun C.S. and Juang J.C., Design and Implementation of a Microsatellite Electric Power Subsystem, Journal of Aeronautics, Astronautics and Aviation, Series A, 44(2), pp. 67-73, 2012.

[5] Jacobsen L.E., Electrical Power System of the NTNU Test Satellite, Master Thesis, Norwegian University of Science and Technology, 2012.

[6] Nishioka K., Takamoto T., Agui T., Kaneiwa M., Uraoka Y. and Fuyuki T., Evaluation of InGaP/InGaAs/Ge triple-junction solar cell under concentrated light by simulation program with integrated circuit emphasis, Japanese Journal of Applied Physics, 43(3R), 882, 2004. 
[7] Yuya Sakurada, Yasuyuki Ota and Kensuke Nishioka, Simulation of Temperature Characteristics of InGaP/InGaAs/Ge Triple-Junction Solar Cell under Concentrated Light, Journal of Applied Physics, 50(4S), 04DP13, 2011.

[8] Dida A.H. and Bekhti M., Study, modeling and simulation of the electrical characteristic of space satellite solar cells, 2017 IEEE 6th International Conference on Renewable Energy Research and Applications (ICRERA), pp. 983-987, IEEE, 2017.

[9] Rezk H. and Hasaneen E.S., A new MATLAB/Simulink model of triplejunction solar cell and MPPT based on artificial neural networks for photovoltaic energy systems, Ain Shams Engineering Journal, 6(3), pp. 873-881, 2015.

[10] Das N., Al Ghadeer A. and Isla, S., Modelling and analysis of multijunction solar cells to improve the conversion efficiency of photovoltaic systems, 2014 Australasian Universities Power Engineering Conference (AUPEC), pp. 1-5, IEEE, 2014.

[11] Hussain A.B., Abdalla A.S., Mukhtar A.S., Elamin M., Alammari R. and Iqbal A., Modelling and simulation of single-and triple-junction solar cells using MATLAB/SIMULINK, International Journal of Ambient Energy, 38(6), pp. 613-621, 2017.

[12] Philipps S.P., Guter W., Welser E., Schöne J., Steiner M., Dimroth F. and Bett A.W., Present status in the development of III-V multi-junction solar cells, Next Generation of Photovoltaic, Berlin, Heidelberg, pp. 1-21, Springer, 2012.

[13] Bett A.W., Dimroth F., Guter W., Hoheisel R., Oliva E., Philipp, S.P., Schöne J., Siefer G., Steiner M., Wekkeli A. and Welser E., Highest efficiency multi-junction solar cell for terrestrial and space applications, Space, 25(25.8), pp. 30-6, 2009.

[14] Yunus Emre Yağan, Kadir Vardar and Mehmet Ali Ebeoğlu, Modeling and Simulation of PV Systems, IOSR Journal of Electrical and Electronics Engineering (IOSR-JEEE), 13(2), pp. 1-11, 2018.

[15] Segev G., Mittelman G. and Kribus A., Equivalent circuit models for triple-junction concentrator solar cells, Solar Energy Materials and Solar Cells, 98, pp. 57-65, 2012.

[16] Thakur M. and Singh B., A MATLAB/Simulink Model of TripleJunction Solar Cell and MPPT Based on Incremental Conductance Algorithm for PV System, International Journal of Engineering Research and Applications, 5(9), pp. 92-95, 2015.

[17] Dey B.K., Khan I., Mandal N. and Bhattacharjee A., Mathematical modelling and characteristic analysis of Solar PV Cell, 2016 IEEE 7th Annual Information Technology, Electronics and Mobile Communication Conference (IEMCON), pp. 1-5. IEEE, 2016.

[18] Sarkar M.N.I., Effect of various model parameters on solar photovoltaic cell simulation: A SPICE analysis. Renewables: Wind, Water, and Solar, 3(1), pp. 13, 2016. 
[19] 3G30C AZURSPACE Triple-Junction Solar Cell, Available at: http://www.azurspace.com/images/products/0004148-0001_DB_GBK_80\%C2\%B5m.pdf (Accessed 21.02.2019)

[20] Theristis M. and O'Donovan T.S., Electrical-thermal analysis of III-V triple-junction solar cells under variable spectra and ambient temperatures, Solar Energy, 118, pp. 533-546, 2015.

[21] Colasanti S., Nesswetter H., Zimmermann C.G. and Lugli P., Modeling and parametric simulation of triple junction solar cell for space application, 2014 IEEE 40th Photovoltaic Specialist Conference (PVSC), pp. 1784-1789, IEEE, 2014.

[22] Bimenyimana S., Asemota G.N.O. and Lingling L., Output Power Prediction of Photovoltaic Module Using Nonlinear Autoregressive Neural Network, Power, 31, 12, 2014.

[23] Priya S. P., Radhika A., and Vinothini T. D., MPPT and SEPIC Based Controller Development for Energy Utilisation in CubeSats, 2012 Annual IEEE India Conference (INDICON), pp. 143-148, IEEE, 2012.

[24] Waghulde D., Kapgate N., Pisal S., Papal S., Gajare T., Rathod B., ... \& Phanse A., Simulation, Design and Implementation of Various MPPT Systems for Micro Cube-Satellite Application, 2016 Second International Innovative Applications of Computational Intelligence on Power, Energy and Controls with their Impact on Humanity (CIPECH), pp. 80-84, 2016.

[25] Li N. Digital control strategies for DC/DC SEPIC converters towards integration, $P h D$ Thesis, Lyon, INSA, 2012.

[26] Zhang, D., AN-1484 Designing a SEPIC Converter, Texas Instruments, 2006.

[27] Jeff F., Designing DC-DC Converters Based on SEPIC Topology, Analog Instrumentation Journal, Texas Instruments, Web. 12, 2016.

[28] ENDUROSAT CubeSat Structure, Available at: https://www.endurosat.com/products/\#power-modules. (Accessed 21.02.2019)

[29] GOMspace Structure, Available at:

https://gomspace.com/Shop/subsystems/power-supplies/nanopowerp31u.aspx (Accessed 21.02.2019) 